\title{
Eğitimde Dijitalleşmenin Oluşturduğu Sosyo-Kültürelliğin Öğretmenin Rolüne Etkisi
}

\author{
The Effects of the Socio-Culturalism Formed by Digitalization in Education \\ on Teachers' Roles
}

\author{
Aynur Erdoğan Coşkun*
}

\begin{abstract}
$\ddot{O} z$
$\mathrm{Bu}$ araştırmanın amacı dijitalleşmenin eğitim-öğretim faaliyetlerine ve öğretmenin rolüne etkisini incelemektir. Araştırma etnografik olarak desenlenen nitel araştırma yaklaşımı çerçevesinde iki akademik başarısı yüksek ve iki akademik başarısı düşük lisede gerçekleştirilmiştir. Araştırmanın katılımcıları kırk öğrenci ve sekiz öğretmenden oluşmaktadır. Araştırmanın verileri; gözlem, yapılandırılmamış ve yarı yapılandırılmış görüşmeler ve alanyazından elde edilen verilerden oluşmaktadır. Veriler tümevarım içerik analizi tekniğiyle çözümlenmiştir. Araştırma bulgularına göre dijitalleşme "karma eğitim" düzeni oluşturmakta ve öğretim kuramları bu eğitim düzeninde öğrenen-öğretenin konumlarını açıklamada yetersiz kalmaktadır. Ayrıca dijitalleşmenin öğretim bilgisini tek-tipleştirerek geleneksel öğretmen rolünü "kolaylaştırıcllık" yönünde değiştirdiği gösterilmiştir. Sonuç olarak, eğitim ortamının sosyo-kültürelliği dikkate alındığında eğitim-öğretimin aktörlerinin bedensel mevcudiyetinin salt dijitalliğe karşı bir direnç oluşturduğu için eğitim düşüncesinin karma eğitimin yeni gereklerine göre geliştirilmesi ve öğretmenin eğitim ve öğretim rolünün yeniden tanımlanması gerekmektedir.
\end{abstract}

Anahtar Kelimeler: Dijitalleşme, eğitim teknolojileri, öğretmenin rolü, kolaylaştırıcı öğretmen, bilginin tek-tipleşmesi.

* Dr. Öğr. Üyesi, İstanbul Üniversitesi Edebiyat Fakültesi Sosyoloji Bölümü, E-posta: aynur.erdogan@istanbul.edu.tr, Orcid ID: https://orcid.org/0000-0002-6625-4869 


\begin{abstract}
The aim of this research is to examine the effects digitalization has had on education/training activities and teachers' roles. The research has been carried out in two high schools with high-academic achievement and in two other high schools with low-academic achievement within the framework of the qualitative research approach using an ethnographic design. The participants consist of 40 students and eight teachers. The data have been obtained from observations, unstructured as well as semi-structured interviews, and the literature. The data have been analyzed using inductive content analysis. According to the research findings, digitalization creates a mixed order of education, and learning theories are insufficient for explaining the positions of the learner and instructor in this educational order. In addition, this study shows digitalization to have changed traditional teachers' roles toward being facilitators by standardizing educational knowledge. As a result, when considering the socio-culturalism of the educational environment, the physical presence of the agents of the education-training activity can be said to create a resistance toward pure digitalism. For this reason, educational thought should be developed according to the new requirements of mixed education, and teachers' educator roles and how they teach should be redefined.
\end{abstract}

Keywords: Digitalization, educational technologies, teachers' roles, facilitator, standardization of knowledge

\title{
Summary
}

\section{Introduction}

Although this study approaches the research subject within the framework of educational sociology, it sometimes uses theoretical explanations from other disciplines. It focuses on the explanations of learning theories regarding the effects educational technologies have on teaching.

Behaviorism, cognitivism, constructivism and socio-cultural learning theory are the basic theories that have been put forth in the field of learning. Behaviorism being concerned with teachers' roles rather than learning processes suggests the need to develop certain educational technologies and mechanical tools. According to Skinner (1958), using special machines developed for learning facilitates education in many ways. While educational technologies change teachers' roles, they do not eliminate the need for teachers. Teachers whose teaching load has become considerably lighter will be able to take on more appropriate roles such as teaching students the requirements for being human.

Unlike behaviorism, cognitivism considers learning to be an internal process that takes place in the mind and forms the basis of intelligent learning systems and artificial intelligence studies (Selwyn, 2011, pp. 70-72). The theory of constructivism argues learning to occur best when based on students' previous experiences and knowledge and on problem solving. Meanwhile, the role of the teacher is to manage and support students' research and discovery process while learning rather than to give direct instructions. At this point, educational technologies are facilitating tools 
for students to increase their knowledge experience through research. Teachers undertake the task of interpreting information that has become standardized through computerized education in accordance with their students' cultural background.

Contrary to the principle that students construct their own knowledge and learning process, the socio-cultural approach emphasizes that learning processes take place in the socio-cultural environment. Socio-cultural learning highlights the role of the teacher as a master and guide not only in training but also in teaching.

The aim of this study is to describe the effect digitalization has had on teachers' teaching and training roles. In this context, the objectives of this study are to describe the relationship students and teachers have with the new technologies in their daily lives and in the educational environment and to show the socio-cultural change digitalization has created in the student-teacher and student-book relationships.

\section{Method}

This study applies the ethnographic design, a qualitative research method. In accordance with the research subject and purpose, two successful and two unsuccessful high schools have been chosen as two opposing sampling areas. In each school, two teachers have been determined with respect to whether they include digital content in their lessons or not. Observations were made in a total of eight classes during one academic semester with observation notes being taken. In-depth interviews have been conducted with the 40 students and eight teachers attending these classes in total. The data have been analyzed using inductive content analysis. The validity of the study has been ensured in terms of credibility, transferability, and reliability.

\section{Findings}

Interactive whiteboards and smart phones have been effective as new tools in students' educational lives and have affected students' daily life practices. Smart phones, which almost every student has, have penetrated students' daily lives and become a tool for their teaching activities due to their areas of multi-purpose usage. The students as research participants spend 2 to 2.5 hours a day on their smartphones. The fact that they mostly use social media to chat and communicate with their friends appears at first glance to show that their relationship with technology socializes students. However, students' preference for short text messages over voice calls signals an escape from real communication (Turkle, 2015, pp. 22-23).

Students' close contact with information technologies is not interrupted while studying or doing homework. When students are studying, doing homework, or wondering about something outside of the classroom, they prefer to browse the internet rather than refer to books. The first tool that students use to access information is not computers, books, or teachers but their smartphones. Students do not read books with their smartphones, as they mostly use their devices 
for accessing social media, playing phone games, and communicating through text messages. In addition to this ethos of smartphones, the fact that smartphones have multiple functions such as communication and web connectivity challenges students' ability to understand the main theme of the text due to the difficulty of focusing their attention on the text they're reading.

Neither students nor teachers find the video lessons prepared by EBA (Educational Informatics Network) sufficient. Teachers and students consider EBA videos to be useless in explaining lecture topics, but they are of the opinion that these videos are effective for seeing three-dimensional figures in lessons such as geography or in watching experiments in lessons such as physics and chemistry. On the other hand, the main reason why EBA videos are not available in classrooms is that they standardize information. A single video content is produced for students at the same learning stage in all schools of the country. Thus, digitalized information rarely matches the real level of the classroom. While EBA lecture videos are found easy and simple by teachers and students of schools with high academic achievement, they are seen as difficult and complex in schools with low academic achievement. The argument that educational technologies support student-centered education was proven to be incorrect in this study.

With the effect information technologies have had on teaching and training, the role of the teacher in the classrooms has evolved from teachers being specialists to teachers being facilitators. Another situation that we observed having emerged among the findings of our study is the increased expectation that teaching materials, teaching-training activities, and teachers should be entertaining. This situation can be explained by the change digitalization has caused for types of information.

\section{Discussion}

Digitalization affects teaching and training actors both in their daily lives and in the classroom. The relationship with digital resources containing educational materials on smart phones has become permanent. Digitalization has brought a change in teachers' roles in educational activities as well as in the relationship students have with teachers and books. One of the most important phenomena of this change is the standardization of knowledge. With this development, although access to digital content is placed in the context of inequality in education with respect to economic and social classes, the main problematic issue in terms of this study's topic is the long-term tendency to digitalize high-cost mass education into a low-cost business line. For this reason, governments have encouraged digitalization. Feenberg (2002, p. 122) emphasized the possibility technology has to eliminate the teaching profession like other traditional professions at this historical stage of technological transformation. The facilitating role that teachers hold as the last grip is limited to teaching.

Although traditional education activities have undergone radical change through digitalization, a strong and qualified teacher should be noted to continue to be the determining factor in educational activities. For this reason, theoretical explanations that define digitalization as only machine learn- 
ing should reinterpret education with respect to mixed education. In addition, this research reveals the need to redefine teachers' teaching and training roles using feedback from the field.

\section{Giriş}

Yeni teknolojilerin eğitim-öğretime etkisi pedagojik, epistemolojik, psikolojik ve sosyolojik açıdan incelenebilir. Hiç şüphesiz bu disiplinlerden biri çerçevesinde yapılan araştırma, diğer disiplinlerle dirsek temasında olacaktır. Bu çalışma, araştırma konusuna eğitim sosyolojisi çerçevesinde yaklaşmakla birlikte zaman zaman diğer disiplinlerin kuramsal açıklamalarından faydalanmaktadır. Bu çerçevede bu çalışma sosyolojik açıdan eğitim-öğretim faaliyetinin aktörlerinin dijitalleşmenin etkisiyle eğitim ortamındaki ilişki biçimlerinin nasıl şekillendiğine odaklanmaktadır. Bu sebeple öğretim kuramları, eğitim teknolojilerinin öğretime etkisine dair geliştirdikleri açıklamalar bağlamında konu edilmektedir.

\section{Teknoloji Eğitim-Öğretimi Değiştiriyor mu?}

Davranışçılık, bilişselcilik, inşacılık ${ }^{1}$ ve sosyo-kültürel öğrenme öğretim alanında ortaya konan temel kuramlardır. Burada bu sırayla bu kuramların eğitim teknolojileriyle ilgili açılkamaları konumuzla ilgisi açısından ele alınmaktadır.

Öğrenme süreçlerinden ziyade öğretmenin rolüyle ilgilenen davranış̧̧ı yaklaşım bir uyarıcıyla karşı karşıya kalan bir insanın belirli bir şekilde yanıt vereceğini (davranacağını) ileri sürmektedir. Sıklıkla insanı uyaran şey, onun bu uyaranla her karşılaştığında nasıl yanıt vereceğini (davranacağını) de belirlemektedir. Bu davranışın sonucunun bir ödülle güçlendirilmesi ya da bir cezayla bastırılması o davranışın tekrarlanma ve dolayısıyla öğrenilme durumunu da etkilemektedir. Bu açılamaların ima ettiği gibi, bu kurama göre, öğrenci büyük ölçüde öğrenme deneyiminin pasif bir alıcısıdır.

1950’lerde davranışçılar ve önemli temsilcilerinden Frederic Skinner, kuramı öğrenen lehine daha fazla geliştirmek amacıyla, "programlı öğretim” modelini geliştirmiştir. Bu program, eğitim müfredatını küçük üniteler biçiminde adım adım planlarken gözlemlenebilir ve ölçülebilir öğretim sonuçlarına odaklanmaktadır. İşte bu noktada davranışçı kuramcılarla teknoloji arasındaki ilişki de gün yüzüne çıkmaktadır. Çünkü programlı öğretim, bazı eğitim teknolojilerinin ve mekanik araçların geliştirilmesini önermektedir. Skinnere (1958) göre, televizyon, işitsel ve görsel kayıt oynatıcıları, projeksiyon ve öğretim için geliştirilmiş özel makineler gibi, eğitim teknolojilerinin sınıfta kullanılması birçok açıdan eğitim-öğretimi kolaylaştırır:

i) Öğretmen ve öğrenciye açıklayıcı ve öğrencinin dikkatini çekici materyal sunabilir;

ii) Öğrencinin öğretim süreçlerine aktif katılımı sağlanabilir;

iii) Mekanik araçların katkısıyla derste doğru cevaba çok hızlı bir şekilde ulaşılabilir;

1 “Constructivism” kavramının karşılığı olarak genel olarak yapıldığı gibi “yapılandırmacılık” yerine "inşacılık” kelimesinin seçilmesinin sebebini Gür (2006: 7) şu şekilde açıklamaktadır: “... "yapılandırma” edilgen anlamları çağrıştırmakta, oysa "construct" fiili bir şeyi kurma ve inşa etme gibi etken anlamları çağrıştırmaktadır. Bu etken vurgu, yaklaşım için vazgeçilmedir, çünkü öğrencinin kendi bilgisini kendisinin inşa ettiğini hatırlatır.” 
iv) Denetlendiğine dair izler gizlenerek ortalama bir öğrencinin her gün istenilen miktarda çalışması sağlanabilir;

v) Öğretmen tek bir araçla eşzamanlı olarak bütün sınıfı daha etkin idare edebilir, öğrenci kendi çapında ilerleme gösterir ve ders boyunca mümkün olduğunca çok problem çözülebilir;

vi) Öğrencinin kişisel becerilerine ve yönelimlerine hitap eden çeşitliliklere yer verilebilir;

vii) Öğrenci okula gelemezse araç sayesinde açığını kapatır;

viii) Üstün yetenekli çocuklar çok hızlı yol alabilir, yine de onlara özel problem setleriyle derslerde çok fazla öne geçmeleri önlenebilir;

ix) Araç karmaşık bir içeriği düzene sokan, özenle tasarlanmış bir eğitim materyalini mümkün kılar.

Eğitim teknolojileriyle öğrenen öğrenci, eğitim materyalleri etkin programlandığı takdirde, klasik eğitimle karşılaştırıldığında çoğunlukla daha etkin öğrendiğine göre Skinner akılları meşgul eden soruya da cevap bulmaya çalışmaktadır: Eğitim teknolojileri öğretmenin yerini alabilir mi? Ona göre, rolü değişmekle birlikte öğretmene olan ihtiyaç ortadan kalkmayacaktır. Zira bu araçlar, emek ve zamanı daha tasarruflu kullanmayı sağlayacaktır. Eğitim için programlanmış makinelerin öğrenci üzerindeki etkisi, özel öğretmenin etkisini çağrıştırmaktadır. Her öğrenci eğitim programı karşısında kendisini özel hissedecektir. Öğretim yükü bir hayli hafifleyen öğretmen ise öğrencilerine insan olmanın gerekliliklerini öğretmek gibi kendisine daha uygun bir rolü daha fazla üstlenebilecektir. Ayrıca dünya çapında her geçen gün artan eğitim talebine, daha tatmin edici bir karşılık üretilmiş olacaktır. Eğitim programı sınırsız sayıda öğrenciye ulaşabileceği için eğitimde ucuz "seri üretim" gerçekleşecektir. Bu da toplumun ekonomik kalkınmasını kolaylaştıracak önemli bir etken olacaktır.

Davranışçılığın aksine bilişselci yaklaşıma göre öğrenme zihinde gerçekleşen içsel bir süreçtir. Öğrenme sürecinde öğrencinin içsel deneyimine odaklandığı için davranışçılık kuramının tam karşısına konumlandırılmaktadır. Bilişselcilik öğrenme için zihnin en ideal şekilde nasıl işlemesi ve gelişmesi gerektiği sorusuna yoğunlaşmaktadır. Bilişselci bilim adamları zihnin işleyişi ile bilgisayarın bilgi işleme süreçlerinin benzerliğinden hareket ettiler ve 1960’lı yıllardan beri teknolojiye dayalı insan öğrenmesinin gelişiminde rol aldılar. "Akıllı öğrenme sistemleri” ve "yapay zekâ" çalışmalarının temelini oluşturan bu öğretim kuramı eğitim-öğretim faaliyetinin tümüne uygulanabilir olmasına rağmen yetişkinlerin öğrenmesinde ve meslekî eğitimde daha etkin kullanım alanına sahiptir. Askerî ve endüstriyel eğitimde simülasyon tabanlı akıllı eğitim sistemlerinin geliştirilmesinde etkili olmuştur (Selwyn, 2011, s. 70-2).

Davranışçı kuramın öğretmen-merkezli yaklaşımına bir tepki olarak 1980’lerden sonra etkin olmaya başlayan inşacılık kuramı, öğrenmenin problem temelli ve öğrencinin önceki deneyimleri ve bilgisine dayandırıldığında en iyi şekilde gerçekleştiğini savunmaktadır. Bu çerçevede öğrenmenin keşif, sorgulama, yorumlama ve anlamlandırma süreçleriyle oluştuğunu kabul ettiği için davranışçı kurama göre öğrenme sürecinde öğrenciye daha aktif bir rol biçilmiş olmaktadır. Bu 
yaklaşıma göre öğrenci sadece dışarıdan bilgi alarak öğrenmez; o bilgiyle kendi deneyimlerini ve bakış açısını geliştirir. Bireysel bir öğrenen olarak öğrencinin belirsiz durumlarda problem çözme yeteneği gelişir.

Öğretmenin rolü ise doğrudan talimat vermek yerine öğrenme sürecinde öğrencinin araştırıp keşfetme sürecini yönetmek ve desteklemektir. Bu noktada eğitim teknolojileri öğrencinin araşt1rarak bilgi deneyimini artırmasında kolaylaştırıcı araçlar olarak görülmektedir. 1980'li yıllardan günümüze kadar, Türk eğitim sistemi de dahil olmak üzere, teknolojikleşen eğitim-öğretim ortamlarında inşacılık kuramının en uygun eğitim-öğretim yaklaşımı sunduğuna dair yaygın bir kanaat oluşmuş bulunmaktadır.

İnşacı yaklaşımın öğrenci-merkezli olma durumunu daha öteye taşıyan Papert’a² göre öğrenenin bilgiyi almasını sağlamanın en iyi yolu onu aktif bir şekilde kendisinin inşa etmesini sağlamaktır. Öğrencileri bir nesne ile bir şey yapmak üzere tahrik ederek onların bu düşünme ve anlama sürecinde başka bir şeyi de nasıl düşüneceklerini öğreneceklerini savunmuştur. Dolayısıyla Papert, öğrenenleri ürettikleri şey ile iletişime geçmeye teşvik etmiş ve eğitim teknolojilerini kendileriyle öğrenilen değil kendilerinden öğrenilen araçlar olarak konumlamıştır (Selwyn, 2011, s. 75).

Papert, öğrencinin bilgiyi öğretmen yerine bir bilgisayardan alıyor oluşunun onu kültürel çevresinden koparacağı iddiasını reddetmiş ve bilgisayar programında çocuğun kültürel çevresinden seçilen metafor ve materyallerle bağın kurulabileceğini savunmuştur. Paperta göre, bilakis bilgisayar, çeşitli nedenlerle zengin eğitim içeriğinden yoksun olan sinıflara belli bir standart sunabilir. Bilgisayar, öğrenmeyi ödül-cezaya bağlayan anlayışı yıkacak; görüntü ve imajların öğrencinin kendi kültürel dünyasındaki bağını ortaya çıkaracak; dolayısıyla doğal ve kendiliğinden öğrenmeyi sağlayacaktır (Papert, 1981, s. 38-39).

Öğrenci-merkezli ve bilgisayarlı eğitim ortamında ahlaki eğitim ya da insan olmanın gerekliliklerinin eğitimi nasıl sağlanacaktır? Bu noktada Papert (1996, s. 63), kamuoyunu meşgul eden paradoksu hatırlatmakta ve etik, ahlak ve din değerlerinin eğitiminin okullar tarafından mı verileceği yoksa ailelerin sorumluluğunda mı kalacağı sorusunu yenilemektedir. Bu soruyu cevaplarken okulların sorumluluğuna da dikkat çekenlere Papert, çok konuşulmayan bir meseleyi gündeme getirerek eğitim teknolojilerinden bağımsız olarak eğitimcilerin öğrenciler nezdindeki güvenirliliğini sorgulamaktadır. Yapılan çalışmalara atıfla öğretmenlerin değerler eğitiminde doğru kişiler olabileceği konusundaki şüpheyi güçlendirmektedir. Diğer taraftan her ne kadar bilgisayarın tam anlamıyla değerler eğitimini gerçekleştireceğini iddia etmese de anlaşılabilir bir amaç ve anlam sağlama bağlamında öğrencinin yalan söylemeye duyabileceği ihtiyacı ortadan kaldırabileceği gibi öğretmene oranla daha güvenilir ve etik bir ilişkiyi sağlayabileceğini savlamış olmaktadır (Papert, 1996, s. 65).

2 Seymour Papert (1928-2016), Geneva Üniversitesinde Piaget ile çalışma imkânı bulmuştur. Bu işbirliği, çocukların matematik düşünmeyi nasıl öğreneceğine dair önemli keşifleri doğurmuştur. MIT Yapay Zekâ Laboratuvarının eş-yöneticiliğini yaparken çocuklar için ilk programlama dili olan Logơyu inşa etmiştir. Papert ilerlemeci eğitim geleneği ile internet çağı arasında köprü işlevi gören bir isim olmuştur. 1989'da Papert'in fikirlerini hayata geçirmek isteyen Avustralya yönetimi, her öğrenciye bir dizüstü bilgisayar sağlamaya başlamıştır. Gelişmekte olan ülkelerde uygulanan "Her Çocuğa Bir Bilgisayar girişimi” de ilhamını Papert'dan almaktadır (Stager, 2016: 308). 
Bilgisayara dayalı ve öğrenci-merkezli eğitim ortamında öğrenci bilgiyi eğitim aracından aldığına göre ve Papert, Skinner’in “insan olmanın gerekliliklerinin” eğitimini öğretmenin sorumluluğuna bırakmasından bir adım daha öteye giderek değer eğitiminde de bilgisayara işlev yüklediği için, elbette eğitim ortamında öğretmenin rolü değişecektir. Geleneksel eğitimde bilginin en önemli kaynağı olan öğretmenin sınıf ortamında edilgen bir konuma düşeceği yönünde eleştirilere yönelik Papert (1981, s. 32, 181) öğretmenin dijitalleşen bilgiyi öğrencinin kültürel çevresine uyarlayıcı rolünün belirginleşeceğini savunarak ona yeni bir rol biçmektedir. Buna göre, öğretmen, bir antropolog gibi kültürel değerleri bilmeli ve güncel kültürel eğilimleri eğitim sürecine (sınırlı) müdahale ederken kullanmalıdır. Böylece bilgisayarlı eğitimle tek-tip haline gelen bilginin öğrencinin kültürel birikimine uygun olarak yorumlanması görevini üstlenmiş olacaktır.

İnşacı öğrenme yaklaşımının öğrenci-merkezli ve öğrenci odaklı olmasının yanı sıra bilgiyi özerk ve çoğu zaman tek başına elde edilen bir şey olarak konumlandırdığı görülmektedir. Buna karşılık, son ylllarda, bireyin öğrenmesini ve bilişsel gelişimini, onu çevreleyen sosyal ve kültürel ortamların etkisiyle birlikte anlama çabalarının öne çıktığı söylenebilir. Bu doğrultuda birçok psikolog öğrenmenin derin bir sosyal süreç olduğu görüşünü savunmaktadır. Öğrencinin kendi bilgisini ve öğrenme sürecini kendisinin inşa ettiği ilkesine karşıt olarak, öğrenme süreçlerinin sosyo-kültürel çevrede gerçekleştiğini vurgulayan sosyo-kültürel öğrenme yaklaşımı Lev Vygotsky'in dahil olduğu bir grup sosyal psikolog tarafından savunulmuştur.

Vygotsky’ye göre, insan eylemi "kültürel araçlar" ya da kaynaklar dediği şeyi içermektedir. Bu araçlar ya da kaynaklar, üretilmiş materyalden teknolojiye, sembol sisteminden dile kadar çeşitlenerek öğrenenin doğal ortamında bulunmaktadır. Bu durumda başarılı bir öğrenci bu kaynakların hepsini, öğrenme eyleminde uygun bir şekilde kullanandır. Özellikle dilin öğrenmenin ayılmaz bir parçası olduğunu vurgulayarak bilişsel gelişim ile sesli ya da iç konuşma arasındaki yakın bağın altını çizmektedir. Bu yakın bağ, insanlar arası etkileşimi, öğrenmenin kaçınılmaz koşulu kılmaktadır. Öğrenme daha az bilenin toplumsal çevresinde daha çok bilenle yaptığı anlam paylaşımlarıyla gerçekleşmektedir. Dolayısıyla öğrenci, kendi başına gerçekleştiremeyeceği öğrenme sürecini daha yetenekli ve bilgili olan ustaların desteğiyle başarabilir ve kendisi bu süreçte yol aldıkça başkalarının desteğine daha az ihtiyaç duyar (Selwyn, 2011, s. 76-77).

Vygotsky (1986, s. 12-57) kendi sosyo-kültürel yaklaşımını açıklarken Piaget’nin öğrencimerkezli eğitim anlayışının dayandığı çocuğun benmerkezcilikten sosyal olmaya doğru geliştiğini savladığı pedagojik anlayışını eleştirmektedir. Çünkü Vygotsky’ye göre çocuk çevresiyle sosyal bir iletişim kurmakta ve yetişkinliğe doğru bu durum benmerkezciliğe ve bireyselliğe doğru bir gelişim seyri göstermektedir. Bu sebeple çocuğun öğrenmesi sosyal iletişimle gerçekleşebilmektedir.

Sosyo-kültürel öğrenme yaklaşımının tesis ettiği eğitim-öğretim ortamına dikkatli bir bakış, sadece eğitimde değil öğretimde de öğretmenin bir usta ve yol gösterici olarak rolünün öne çıktı̆̆ını farkedecektir. Çünkü öğretmen, öğrenmenin gerçekleşmesi için bir koşul olarak öne sürülen insanî etkileşimi gerçekleştiren aktör haline gelmektedir. Vygotsky’nin görüşlerine ve sosyo-kültürel öğrenme yaklaşımına dayanarak eğitim-öğretim mekanlarında öğrenciyi sosyal gerçekliğin parçası kılan ortamların hazırlan- 
ması artık daha fazla istenen bir durum haline gelmeye başlarken bilgisayarlı eğitimin toplumsal olarak "zenginleștirilmiş" biçimleri destekleyeceği varsayılabilir mi? Sosyo-kültürel öğrenme yaklaşımının eğitim teknolojileriyle öğrenmenin bunu ne kadar desteklediğiyle ilgili geliştirilmesi gerekmektedir.

$\mathrm{Bu}$ araştırma ise iki açıdan önem taşımaktadır. İlki, eğitim-öğretimin dijitalleşmesi bağlamında çağdaş eğitim sisteminde bir sürecin etnografik olarak sosyo-kültürel tasvirini sunmasıdır. İkincisi, öğretim içeriğinin dijitalleşmesinin eğitim-öğretimin aktörlerinin rol ve faaliyetlerinde meydana getirdiği değişimi göstermesidir. Bu çerçevede bu çalışmanın amacı, dijitalleşmenin öğretmenin eğitim ve öğretim rollerine etkisini betimlemektir. Bu kapsamda öğrenci ve öğretmenlerin gündelik hayatlarında ve eğitim-öğretim ortamında yeni teknolojilerle ilişkilerini tasvir etmek; dijitalleşmenin öğrenci-öğretmen ve öğrenci-kitap ilişkiselliğinde meydana getirdiği sosyo-kültürel değişimi göstermek çalışmanın hedeflerini oluşturmaktadır.

\section{Yöntem}

\section{Araştırmanın Deseni}

$\mathrm{Bu}$ çalışmada nitel araştırma yöntemi olan etnografik desen uygulanmıştır. Etnografya "bir kültür paylaşım grubunun zaman içinde gelişen ortak dil, inanç ve davranış örüntülerini tanımlamaya, analiz etmeye ve yorumlamaya" (Creswell, 2017, s. 600) imkân tanır. Etnografik yöntem ile bir grubun kültürü onların bakış açısıyla betimlenebilir (Hatch, 2002, s. 21). İnsanların görüşlerini onların kendi ortamlarında gözlemleyerek anlamak ve yeni bir kuram geliştirmek için etnografi uygun bir yöntemdir. Kültür grubunun doğal ortamında gerçekleştirilen görüşmelerin dişında, gözlem etnografide öncelikli veri toplama stratejisidir (McMillan \& Schumacher, 1989, s. 382). Okul öğretmen, öğrenci ve yöneticileriyle günlük ritüel ve törenlerinin gelenekselleşerek belirli kurumsal değer ve inançların oluştuğu bir kültür ortamıdır (Stolp \& Smith, 1995, s. 8). Okul çalışmalarında eğitim-öğretimin aktörlerinin kültürel yönelimlerinin anlaşılmasında etnografi uygun bir yöntem olarak öne çıkmaktadır. Özellikle eğitim teknolojilerinin yeni bir unsur olarak okul kültürünü yeniden şekillendirdiğinden hareketle (Kitchenham, 2009) kuramsal doygunluğa ulaşılmayan bu alanda etnografik gözlem önem kazanmaktadır. Bu çalışmada araştırmacı iki eğitim-öğretim dönemi boyunca sınıf ve diğer okul ortamlarında gözlem yapmış ve ardından görüşmeler gerçekleştirerek teknolojinin eğitim-öğretim faaliyetlerini ve kültürünü nasıl etkilediğini betimlemeye çalışmıştır.

\section{Çalışma Grubu}

Nitel araştırmada amaçlı örnekleme yöntemi kullanılır ve "uygun" katılımcılara ulaşmak için araştırmacı tarafından "uygun” araştırma alanları seçilir. Katılımcıların aykırı ya da tipik durumları örneklemeleri (Seggie \& Akbulut Yıldırmış, 2015, s. 28) araştırmanın konu ve amaçlarına göre tercih edilebilen örnekleme yollarındandır. Bu çalışmada araştırma konusu ve amacına uygun olarak iki 
başarılı ve iki başarısız lise aykırı iki örneklem alanı olarak seçilmiştir ${ }^{3}$. İki başarılı lise liseye giriş sınavında yüzde üçlük, iki başarısız lise ise yüzde ellilik başarı diliminde yer almaktadır. Okul müdürlerinden görüş alınarak -yine aykırı iki örneklem olarak- her okulda derslerinde dijital içeriğe yer veren ve vermeyen birer öğretmen ve dersi belirlenmiştir. Matematik, dil (Arapça, İngilizce), biyoloji ve edebiyat derslerinin işlendiği toplam sekiz sınıfta yarım dönem boyunca gözlem yapılmış ve gözlem notları kayda geçirilmiştir. Ayrıca odalarında yapılan yapılandırılmamış görüşmelerde bu okulların yöneticileri ve öğretmenlerinin araştırma konusuyla ilgili görüşleri alınmıştır. Ardından gözlemci olarak dahil olunan sınıflardan gönüllü olan ve araştırmacının gözlemler sırasında eknolojiye ilgileriyle dikkatini çeken öğrencileri davet etmesi yoluyla toplamda kırk öğrenciyle ${ }^{4}$ ve bu derslere giren sekiz öğretmenle ${ }^{5}$ derinlemesine görüşme gerçekleştirilmiştir. Öğrenci çalışma grubu teknolojiyle ilişkileri bakımından tipik bir durumu örneklendirmiştir.

Tablo 1.

Öğrencilerden Oluşan Çalışma Grubu

\begin{tabular}{|c|c|c|c|}
\hline \multicolumn{4}{|c|}{ Lise-1 - Akademik Başarısı Yüksek Lise } \\
\hline Öğrenci & Sinıfi & Sosyal Medya Hesabı & Günlük internet kullanımı \\
\hline Enes & 9 & Facebook, Twitter... & 3-4 saat \\
\hline Fatih & 9 & Facebook & Hava kötüyse tüm boş vakitlerinde \\
\hline Özlem & 9 & Instagram, Whatsapp, Snapchat & Yarım saat \\
\hline Elif & 9 & Whatsapp, Tumblr & 1 ya da 1.5 saat \\
\hline Hatice & 9 & Instagram, Tumblr, Snapchat, Whatsapp & 2 saat \\
\hline Feride & 10 & Twitter, Facebook, Snapchat & 3 saat \\
\hline Duygu & 10 & Twitter, Facebook, Snapchat & 2 saat \\
\hline Demet & 10 & Facebook, Snapchat, Whatsapp & 3 saat \\
\hline Çiğdem & 10 & Snapchat, Whatsapp & 2 saat \\
\hline Ekrem & 10 & Facebook Messenger & Akıllı telefon kullanmiyor \\
\hline \multicolumn{4}{|c|}{ Lise-2 - Akademik Başarısı Yüksek Lise } \\
\hline Öğrenci & Sinıfi & Sosyal Medya Hesabı & Günlük internet kullanımı \\
\hline Ümit & 9 & Whatsapp & 3 saat \\
\hline Esma & 9 & Twitter, Facebook, Instagram, Askfm & 4 saat \\
\hline Ebru & 9 & Facebook, Instagram, Whatsapp & 2 saat \\
\hline Turgut & 9 & Snapchat, Facebook, Twitter & 1.5 saat \\
\hline Zehra & 9 & Instagram, Tumblr, Twitter, Snapchat & 1 saat \\
\hline Taner & 11 & $\begin{array}{l}\text { Twitter (nadir), Facebook (nadir), Instagram, } \\
\text { Whatsapp }\end{array}$ & 2 saat \\
\hline Kübra & 11 & Facebook, Twitter, Instagram, Snapchat, Vine, Tumblr & 2 saat \\
\hline Selma & 11 & Twitter, Instagram, Whatsapp & 3-4 saat \\
\hline Sinan & 11 & Twitter, Instagram, Snapchat & $2-3$ saat \\
\hline Sedat & 11 & Twetter, Facebook, Instagram & 4 saat \\
\hline
\end{tabular}

3 Liselerin isimlerine etik açıdan yer verilmemektedir. Bu dört lise İstanbul'un Fatih ilçesinde yer almaktadır. Tablo- 1 ve Tablo-2'de rumuzlarıyla yer verilen öğretmen ve öğrencilerin liseleri rakamla ifade edilmiştir. Bunlardan 1 ve 2 numaralı liseler akademik başarısı yüksek, 3 ve 4 numaralı liseler ise akademik başarısı düşük liselerdir.

4 Bu kırk öğrencinin her birine bir rumuz verilmiştir. Metin içerisinde öğrencilere bu rumuzlarla ve devam ettikleri okula atfedilen numara ile atıf yapılmaktadır. Örneğin "Enes-1" akademik başarısı yüksek 1 numaralı okulun öğrencisidir. Öğrencilerle ilgili bilgi için bkz.: Tablo-1

5 Bu sekiz öğretmen için metinde rumuzlar ve okullarına atfedilen numaralar kullanılmıştır. Öğretmenlerle ilgili bilgi için bkz.: Tablo-2 
Eğitimde Dijitalleşmenin Oluşturduğu Sosyo-Kültürelliğin Öğretmenin Rolüne Etkisi

\begin{tabular}{|c|c|c|c|}
\hline \multicolumn{4}{|c|}{ Lise-3 - Akademik Başarısı Düşük Lise } \\
\hline Öğrenci & Sinifi & Sosyal Medya Hesabı & Günlük internet kullanımı \\
\hline Adem & 10 & Instagram, Facebook & 2 saat \\
\hline İsmail & 10 & Instagram, Facebook & 1 saat \\
\hline Ali & 10 & Instagram, Snapchat, Whatsapp & Çok fazla değil \\
\hline Alper & 10 & Facebook, Twitter, Instagram, Whatsapp & 2 saat \\
\hline Arda & 10 & Instagram, Snapchat, Whatsapp & - \\
\hline Barış & 10 & Instagram, Facebook, Snapchat, Askfm, Connected & $6-7$ saat \\
\hline Mehmet & 11 & Instagram, Facebook, Snapchat, Whatsapp & $2-3$ saat \\
\hline Bilal & 11 & Instagram, Facebook, Whatsapp & 1 saat \\
\hline Recep & 11 & Instagram, Facebook, Whatsapp & Bazen çok, bazen az \\
\hline Cezmi & 11 & Instagram, Facebook, Whatsapp & Boş kaldıkça tüm gün \\
\hline Talha & 11 & Instagram, Facebook, Snapchat, Whatsapp & 3-4 saat \\
\hline \multicolumn{4}{|c|}{ Lise-4 - Akademik Başarısı Yüksek Lise } \\
\hline Öğrenci & Sinifi & Sosyal Medya Hesabı & Günlük internet kullanımı \\
\hline Leyla & 9 & Instagram, Twitter, Whatsapp & Çok \\
\hline Yeşim & 9 & Instagram, Whatsapp & 2 saat \\
\hline Kevser & 9 & Snapchat, Instagram, Whatsapp & 2.5 saat \\
\hline Nevin & 9 & Instagram, Facebook, Whatsapp & Hafta sonları \\
\hline Melek & 9 & Instagram Snapchat, Whatsapp Onedio, Ekşi Sözlük & $\begin{array}{l}\text { Her zaman... Telefon için boş vakit } \\
\text { yaratıyorum. }\end{array}$ \\
\hline Ayperi & 10 & Facebook, Instagram, Whatsapp & 1 saat \\
\hline Fatma & 10 & Facebook, Instagram, Whatsapp & 4 saat \\
\hline Meryem & 10 & Snapchat, Whatsapp & 3-4 saat \\
\hline Zeynep & 10 & Instagram, Whatsapp & Boş kaldığım her zaman \\
\hline
\end{tabular}

Tablo 2.

Öğretmenlerden Oluşan Çalışma Grubu

\begin{tabular}{|c|c|c|c|c|c|c|}
\hline Öğretmen & Lise & $\begin{array}{l}\text { Gözlemlenen } \\
\text { Dersi }\end{array}$ & $\begin{array}{c}\text { Derslerinde } \\
\text { Dijital Materyal }\end{array}$ & $\begin{array}{l}\text { Görev } \\
\text { Yilı }\end{array}$ & Sosyal Medya & $\begin{array}{c}\text { Sosyal Medya Kullanma } \\
\text { Durumu }\end{array}$ \\
\hline Arzu & 3 & Matematik & Kullanmiyor & 7 yil & Facebook, Whatsapp & Pasif (mesleki kullanım) \\
\hline Nazan & 3 & Arapça & Kullaniyor & 3.5 yll & $\begin{array}{l}\text { Facebook, Instag- } \\
\text { ram, Whatsapp }\end{array}$ & Aktif \\
\hline Nilgün & 4 & Biyoloji & Kullanmiyor & 29 y1l & Facebook & Pasif (özel paylaşımlar) \\
\hline Şevket & 4 & İngilizce & Kullanıyor & $20 \mathrm{yll}$ & Facebook & Pasif (mesleki kullanım) \\
\hline Remzi & 2 & Edebiyat & Kullaniyor & - & $\begin{array}{l}\text { Facebook, Twitter, } \\
\text { Instagram }\end{array}$ & Aktif \\
\hline Kemal & 2 & Matematik & Kullanmiyor & 35 yıl & Yok & Kullanmiyor \\
\hline Fehmi & 1 & Edebiyat & Kullaniyor & 15 y1l & $\begin{array}{l}\text { Instagram, What- } \\
\text { sapp }\end{array}$ & Aktif (günlük haber) \\
\hline Halil & 1 & Dil Anlatım & Kullaniyor & 21 yıl & Facebook & Aktif \\
\hline
\end{tabular}

\section{Veri Toplama Aracı ve Verilerin Toplanması}

Araştırma verileri yapılan gözlemlerde kaydedilen notlardan ve yapılandırılmamış ve yarı yapılandırılmış görüşmeler ile elde edilen bilgilerden oluşmaktadır. 2016 yılı bahar döneminde iki lisede ve 2017 yılı bahar döneminde diğer iki lisede sekiz dersin işlendiği dersliklerde, derslerin 
işlendiği süre boyunca en arkada oturularak, derslere hiçbir şekilde müdahil olunmayarak gözlem yapılmış ve gözlem notları kaydedilmiştir. Gözlemin başında dersin öğretmeni araştırmacıyı sınıfa takdim etmiş ve bir araştırma amacıyla sınıfta bulunduğunu açıklamıştır. Gözlem boyunca araştırmacı ile öğretmenler ve öğrenciler arasında tanışıklık oluşmuş ve yapılandırılmamış görüşmelerde araştırma konusu ile ilgili bilgi alınmıştır. Oluşan tanışıklıktan dolayı öğretmen ve öğrenciler araştırmacıyı spor müsabakaları gibi öğrenci etkinliklerine davet etmiş ve bu tür faaliyetler araştırmacı ile katılımcılar arasındaki güveni beslemiştir. Aynı zamanda kurulan yakın ilişkiler gözlem sırasında edinilen izlenimlerin konuşularak daha iyi anlaşılmasına imkân tanımıştır. Gözlemlerde kaydedilen notlardan, yapılandırılmamış görüşmelerden ve alanyazından elde edilen bilgilere dayanılarak yarı yapılandırılmış görüşme formları hazırlanmıştır.

Yapılandırılmamış görüşme, hakkında yeterli bilgiye sahip olunmayan fenomenlerle ilgili yapılacak görüşmelerin sorularını hazırlamak için araştırmacının başvurduğu açık-uçlu ve esnek görüşmedir. Yarı yapılandırılmış görüşme ise görüşmeden önce esnek olarak hazırlanmış sorularla gerçekleştirilir ve görüşmenin büyük kısmı sorularla yönlendirilir (Merriam, 2009, s. 89). Görüşme formunda öğrencilerin gündelik hayatlarında ve öğrenirken teknolojiyle ilişkileri ve öğretmene, kitaba, çevrimiçi kaynaklara bakışları sorulaştırılmıştır. Öğretmenler ile görüşmelerde ise gündelik hayatlarında ve eğitim-öğretim faaliyetlerinde teknolojiyle ilişkileri ve öğretmenin eğitim ve öğretim misyonuyla ilgili düşünceleri sorulmuştur.

\section{Verilerin Çözümlenmesi ve Değerlendirilmesi}

Eğitim-öğretim faaliyetlerinin değişmesinde teknolojinin kültürel etkisinin çözümlenmesi bir kuramsal çerçeveden hareket ederek ya da bir kuramı test etmek için değil, bu konuda yeni bir kanıya varmak amacıyla yapılmaktadır. Bu sebeple saha araştırmasından ve alanyazından elde edilen veriler çözümlenirken tümevarım içerik analizi tekniği kullanılmıştır. Bu bağlamda verileri içeren metinler kodlama, kategoriler yaratma ve özetleme aşamalarına tabi tutulmuştur (Kızıltepe, 2015, s. 258). Gözlem esnasında kaydedilen notlardan, görüşmelerin ses kayıtlarının deşifresinden ve alanyazından elde edilen bilgi içeriğinden meydana gelen metinlerde kodlama yapılmıştır. İfadeler birbiriyle ilişkilendirilerek oluşturulan kodlardan kategoriler oluşturulmuştur. Birbiriyle ilişkili kategoriler özetlenerek temalar çıkarılmıştır. Gündelik hayatta teknoloji kullanımı, sınıfta eğitim teknolojileri, kitap ve çevrimiçi kaynaklarla ilişkiler, bilginin tek-tipleşmesi ve öğretmenin değişen rolü tematik çerçeveyi oluşturmuştur.

Verilerin değerlendirilmesinde etnografik desenin türlerinden olan gerçekçi etnografya uygulanmıştır. Bu çerçevede üçüncü tekil şahıs ifadesiyle gözlemler aktarılmış ve gözlemler, görüşler kişisel yargıdan uzak bir şekilde nesnel olarak raporlaştırılmıştır. Gözlemlenen sınıflardaki eğitim-öğretim sürecinin -konu bağlamında- olağan detayları aktarılmıştır. Diğer taraftan katılımcıların görüşleri yer yer birebir alıntılarla aktarılsa da araştırmacı konunun sunumu ve yorumu konusunda son sözü söyleyendir (Creswell, 2017, s. 603). Sinıf etosunun sosyolojik analizinde araştırmacının yorumlayıcı bakışı etkilidir. 


\section{Geçerlik ve Güvenirlik}

Nitel araştırmada geçerlik ve güvenirliğin sağlanması, araştırmanın etik bir şekilde yürütülmesini içerir. Nitel araştırmada ortaya çıkması muhtemel etik sorulara ilişkin araştırmacı vardığı sonuçların "mantıklı" olduğunu gösterecek kadar ayrıntılı betimleme yapmaktadır. Bu etik sorular geçerlik ve güvenirlik çerçevesinde araştırmanın inanılırlık, nakledilebilirlik ve güvenilebilirliği bağlamında oluşmaktadır (Merriam, 2009, s. 209-235). İnanılırlık, ayrıntılı betimleme ve katılımcıların tasviri ile mümkün olmaktadır. Bu çalışmada öğretmen ve öğrencilerin teknolojiyle ilişkisi ayrıntılı betimlenirken katılımcıların özellikleri olabildiğince açılanmaktadır. Ayrıca gözlem sırasında araştırmacının vardığı kanaatler araştırmacı tarafından yapılandırılmamış ve yarı yapılandırılmış görüşmelerde katılımcılara teyit ettirilerek inanılırlık düzeyi artırılmıştır. Nakledilebilirlik, katılımcılardan doğrudan alıntılar yapılarak, okuyucunun anlayabileceği sadelikte bir dil kullanılarak ve veriler ayrıntılı bir biçimde betimlenerek sağlanmıştır. Güvenilebilirlik, bir çalışmanın iç tutarlılığıyla ilgilidir ve buna yönelik en yaygın kullanılan strateji "üçgenleme" tekniğidir; birden fazla veri toplama yönteminin kullanılmasıyla sağlanır. Gözlemin yanı sıra görüşme teknikleri de çeşitlendirilerek bu çalışmada güvenilebilirlik oluşturulmaya çalışılmıştır.

\section{Bulgular}

\section{Gündelik Hayatta Teknoloji Kullanımı}

Öğrencilerin eğitim teknolojisiyle ilişkisini sınıftaki etkileşimli tahtayla sınırlı tutmak yanıltıcı olacaktır. Özellikle neredeyse her öğrencinin sahip olduğu akıllı telefonlar çok amaçlı kullanım alanlarından dolayı, öğrencilerin gündelik hayatlarına nüfuz etmiş ve onların öğretim faaliyetlerinin de bir aracı haline gelmiştir. Akıllı telefonlar öğrencilerin teknolojiyle ve sanal ağlarla ilişkisini kesintisiz kılmaktadır. Ulaşılması kolay ve hızlı olduğunu düşündükleri için, derslerine dair veya merak ettikleri herhangi bir konuda bilgiye ulaşmaya çalışırken bilgisayar yerine akıllı telefonlarını tercih etmektedirler. Bu sebeple öncelikle öğrencilerin gündelik hayatlarında bilgi teknolojileri ile ilişkilerinin onların bilgi ve öğretmenle ilişskisine nasıl etki ettiğini sorgulamak gerekmektedir.

Öğrencilerin bilgi teknolojileri ile ilişkilerinin kesintisiz olduğunu söylemek abartı olmayacaktır. Duygu-1, boş kaldığında ve dinlenirken telefonuyla vakit geçirdiğini ifade ederken ders sürecinde bile telefonuyla meşgul olan öğrenciler gözlenebildiğine göre telefonla meşguliyet boş vakit sınırlarını zorlamaktadır. Nitekim Sinan-2, teneffüslerde telefonla vakit geçirdiklerini ve derslerde de zaman zaman telefonlarına baktıklarını söylemektedir. Çalışma grubundaki öğrencilerin telefonlarıyla meşgul oldukları süre; toplamda başarılı liselerde 3-4 saat daha az olmak üzere, öğrenci başına günde 2 ila 2,5 saat olarak hesaplanmıştır ${ }^{6}$. Bu meşguliyet süresinin içeriği sorgulandığında öğrencilerin ifade ettikleri sürenin daha fazla olabileceği düşünülebilir. Zira öğrenciler eğitim-öğretim kapsamının dışında kalan gündelik hayat faaliyetleri kapsamında müzik dinleyerek, film ya da temalı videolar izleyerek, tek oyunculu ya da çok oyunculu oyunları oynayarak ve sosyal medya web sitelerini takip etmek amacıyla akıllı telefonlarını kullanmaktadırlar.

6 Bkz. Tablo-1 
Öğrencilerin içinde sosyal medyada etkileşime girenlerin sayısı oldukça azdır. İmam Hatip Lisesi öğrencileri Adem-3, Ali-3, Alper-3 ve Bilal-3 dini, siyasi ve ideolojik içeriğe sahip paylaşımlarda bulunduklarını söylerken diğerleri pasif konumda izleyici olduklarını bildirmektedir. Bu pasif konum eğlence içerikli paylaşımları, arkadaşların yüklediği fotoğrafların izlenmesini ve siyasi gündemin takip edilmesini içermektedir. Diğer taraftan sosyal medya kullanmaya yönelik olarak en çok ifade edilen amaç, arkadaşlarla sohbet etmek ve haberleşmek olmuştur. Bu durumda okulla ilgili meselelerin oluşturulan "Whatsapp grupları" vasıtasıyla konuşulmasının etkisi büyük görünmektedir. Aynı zamanda her dersin öğretmeniyle birlikte oluşturulan gruplar da derslere ilişkin yazışmaları sağlamaktadır. Bu gruplar ayrıca öğrencilerin öğretmenlerine dersle ilgili soru yöneltebileceği ve öğretmenlerin öğrencilerine dersin dışında eğitim-öğretim içeriği paylaşabildikleri platformlar haline gelmektedir. Ders dışı bu platformlarda öğrencilerin istirahat saatlerinde yazmamaları ve yazdıklarında adabı muaşeret kurallarına uyuyor olmaları hem öğrenciler tarafından ifade edilmiş hem de öğretmenler tarafından teyit edilmiştir. Öğretmen Fehmi-1 "şu saatte atmayın diye bir şey söylemememize rağmen, onlar belli bir saatte kendi aralarındaki konuşmaları da kesebiliyorlar" diyerek öğrencilerin ders dışı bu platformu istismar etmediklerinin altını çizmektedir.

Sosyal medyayı en fazla arkadaşlarıyla sohbet etmek ve haberleşmek için kullanıyor oluşları, ilk bakışta teknolojiyle ilişkilerinin öğrencilerin toplumsal bağlarını güçlendirdiğini düşünmemizi sağlamaktadır. Boş zamanlarında arkadaşlarıyla vakit geçirmeyi mi bilgisayar/telefonla meşgul olmayı mı tercih ettiklerini sorduğumuzda arkadaşlarını tercih edenlerin sayısının daha fazla oluşu bu kanaati destekleyebilir. Ancak öğrencilerin sesli arama yerine kısa metin mesajlarını tercih etmeleri sohbete ve haberleşmeye farklı bir anlam yüklediklerini düşünmemize sebep olmaktadır. Turkle (2015, s. 22-23), teknolojinin insanlar arası iletişime yaptığı olumsuz etkiyi gösterdiği çalışmasında kısa metin mesajlarının gerçek iletişimden kaçış anlamına geldiğini ifade etmektedir. Gerçek iletişimde bazen konuşma kişilerin istemediği bir hal alabilir. Ancak bu doğaçlama hali, önceden tahmin edilemeyen yeni bir bilginin keşfine de yol açabilir. Ayrıca yüz mimikleri ve beden dili iletişimi kolaylaştırır. Kısa metinle iletişim ise bu avantajlara sahip olmamakla birlikte kişiye ne diyeceğiyle ilgili ve muhatabıyla ne kadar iletişime geçeceğiyle ilgili tam bir kontrol sağlamaktadır. Kısa metin mesajlarıyla kontrollü olmayı seçen insanlar aslında daha az ve kontrollü iletişimi ve yalnızlığı seçmektedirler ve gerçek iletişimden uzaklaşmaktadırlar.

Öğretmenlerin bilişim teknolojileriyle ilişkileri öğrencilerine nispetle daha sınırlı olmakla birlikte gündemi takip etmek, öğrencilerle iletişime geçmek, onlarla dersleriyle ilgili bilgi paylaşımında bulunmak gibi amaçlarla bu teknolojilerle ilişki gündelik hayatlarının bir parçası haline gelmiş görünmektedir. Hepsi akıllı telefona sahip olsa da öğretmenlerden dördü Whatsapp gibi platformlar üzerinden öğrencileriyle eğitim-öğretim içerikli paylaşımlarda bulunmakta ve onların derslerle ilgili sorularına cevap yazmaktadır (Arzu-3, Şevket-4, Remzi-2, Fehmi-1, Nazan-3). Bu öğretmenler aynı zamanda sosyal medya hesaplarına da sahipler. Hangi platformlar olduğunu sorduğumuzda öğrenciler kadar çeşitli mecraları saymamakla birlikte Facebook ortak platform olarak öne çıkmaktadır. Halil-1 de Facebook hesabına sahip olsa da bu platformu derslerle ilgili bir mecra olarak kullanmaktadır ve öğrencileri bu kanal üzerinden kendisiyle iletişime 
geçebilmektedir. Nilgün-4 telefonunu sadece konuşma amacıyla kullandığını söyleyerek aile fertlerinin açtığı bir Facebook hesabına sahip olduğunu ve aktif bir kullanıcı olmadığını söylemektedir. Sosyal medya hesabına sahip olmayan Kemal-2 ise akıllı telefonuyla gündemi takip etmek amacıyla gündelik faaliyetleri kapsamında meşgul olmaktadır. 16 yıllık mesleki tecrübeye sahip ve alanında doktora derecesi almış Edebiyat öğretmeni Remzi-2 en aktif akıllı telefon ve sosyal medya kullanıcısı olarak öne çıkmaktadır. Sosyal medya platformları üzerinden öğrencilerini takip etmekte ve "yaşına, aile terbiyesine yakışmayan” paylaşımlarda bulunanları ertesi gün yanına çağırarak onlara nasihat etmektedir. Neredeyse bütün öğrencilerin derse katılımını sağlayabildiği gözlemlenen Remzi-2, derse katılmayan ya da yanlış davranışlarda bulunan öğrencileriyle de, onları sınıf ortamında utandırmamak için, sosyal medya kanalıyla iletişim kurmaktadır. "Bunda benim zihniyet ve kişilik olarak teknoloji kullanımına açık olmamın ve gençlere yakın olmamın etkisi var” diyen Remzi-2 öğretmenlerin bu çağın çocuklarını yakalamanın yollarını keşfetmek zorunda olduğunu düşünmektedir.

Diğer taraftan Remzi-2 için sosyal medyanın sadece öğrencileriyle iletişim kurma aracı olduğu, onun ders hazırlıklarında çevrimiçi kaynaklar yerine zengin kütüphanesine başvurduğunu vurgulamasından anlaşılmaktadır. Benzer bir eğilim Fehmi-1 tarafından da dillendirilmiştir. Derslerinde çevrimiçi kaynakları kullanarak Youtube videolarını öğrencilerine izleten, akıllı telefonunu aktif kullanan, ancak derslerinde daha fazla öğretmen merkezli bir öğretim tarzı uygulamakla birlikte öğrencilerine “insanî” mevzuları anlattığı için öğrencileri (Elif-1, Hatice) tarafından rol model olarak görülen, 15 ylllık mesleki tecrübeye sahip Edebiyat öğretmeni Fehmi-1 de derslerine hazırlanırken kitapları tercih etmektedir. Teknolojiyle ilişkisi sınırlı, derslerinde disiplinli ve öğretmen merkezli öğretme tarzını benimseyen, 29 yıllık mesleki tecrübeye sahip Biyoloji öğretmeni Nilgün-4'ün çevrimiçi kaynaklara başvurmadığını ifade etmesi ise şaşırtıcı görülmemektedir. Bu üç öğretmenin dışındaki beş öğretmen ise derslerine hazırlanırken çeşitli düzeylerde çevrimiçi kaynaklara başvurmaktadırlar.

\section{Sinif Etosu}

Öğrencilerin eğitim-öğretim hayatlarında etkin hale gelen yeni araçlar, FATİH Projesi kapsamında kullanıma giren etkileşimli tahtalar ile öğrencilerin gündelik hayat pratiklerini de etkileyen akıllı telefonlardır. Sınıflarda hem öğrenciler hem öğretmenler tarafından farklı düzeylerde kullanılan etkileşimli tahtaların sınıflarda ders yapma pratikleri çerçevesinde çeşitli işlevler yerine getirdiği gözlenmiştir:

a) FATİH Projesi kapsamında içerik üretmek amacıyla oluşturulan EBA (Eğitim Bilişim Ağı) ders materyallerine ulaşım etkileşimli tahtalar sayesinde sağlanmaktadır. Etkileşimli kitaplar, soru bankaları, üç boyutlu modeller, dinamik uygulamalar (matematik, fizik, biyoloji), deneyler (fizik, biyoloji, kimya) ve müfredata uygun bir şekilde üretilmiş konu anlatımı videoları EBA içeriğini oluşturmaktadır. Gözlemlerimize ve öğretmenlerin ifadelerine göre sekiz öğretmenin arasında Edebiyat öğretmeni Fehmi-1 ve Din Anlatım öğretmeni Halil-1 dersinde EBA ders anlatım videolarını izletmektedir. Ayrıca öğrencilerin ifadelerine göre Coğrafya, Fizik, Biyoloji ve Kimya 
derslerinde öğretmenler EBA materyallerinden derslerinin konularını destekleyen dinamik uygulamaları ve deney videolarını izletmektedirler.

b) Etkileşimli tahtalar öğrencilerin ödev olarak hazırladıkları sunumlarını gerçekleştirirken kendilerini ifade etmek için yardım aldıkları görsellerin sınıfta kolayca gösterilmesini sağlamaktadır. Örneğin Biyoloji öğretmeni Nilgün-4 derslerinde etkileşimli tahtayı kullanmamasına rağmen öğrencilerinin sunumlarında EBA görsellerini kullanmalarını desteklemekte; özellikle laboratuvarın ve laboratuvar malzemelerinin eksik kaldığı yerde deney videolarının faydalı olacağını kabul etmektedir. Ancak kendisinin aktif akıllı telefon kullanıcısı olmadığı gibi derslere hazırlanırken de çevrimiçi kaynaklardan değil sadece kitaplardan faydalandığının altını çizerek etkileşimli tahtayı kullanabilmek için eğitime ihtiyaç duyduğunu ve verilen eğitimin yetersiz kaldiğını ifade etmektedir.

c) EBA çevrimiçi bir sosyal eğitim platformudur. Bu sosyalliğin sınıflara yansıyan boyutunu bir dönem öğrencilere dağıtılan ve sonra dağıtımı durdurulan tabletler sağlıyordu. Tabletler sayesinde etkileşimli tahtalarla öğrencilerin tam bir etkileşiminin sağlanacağı varsayılmıştı. Tabletleri olan 10. ve 11. sınıf öğrencileri sadece Tarih öğretmeninin dersini tabletle birlikte işlediğini ifade etmektedir. Tabletin verimli kullanılamamasının en önemli sebebi her okulda yeterli internet alt yapısının olmayışının yanı sıra dersin verimli işlenememesinden dolayı öğretmenlerin tercih etmemesidir. Zira öğrencilerin çoğu, Öğretmen Fehmi-1 ve Halil-1 ve öğrencilerin ifade ettiği gibi, tabletlerine oyun yüklemekte, mümkün olmamasına rağmen yazılımında değişiklikler yaparak internete bağlamakta ve onları eğitim materyali olma işlevlerinin dışında kullanmaktadır. Bu sebeple etkileşimli tahtaların ders sürecinde öğrencinin doğrudan katılımını sağlayan işlevi devre dışı kalmaktadır.

d) Etkileşimli tahtaların bir işlevi ve işlevsizliği de sınıfların akademik başarı düzeyiyle ilgili olarak, özellikle matematik ve geometri derslerinde ortaya çıkmaktadır. Geometrik şekillerin gösterilmesi, dönen cisimlerle boyutluluğun kavranması ve yardımcı kaynaklarla daha fazla problem çözülmesi noktasında etkileşimli tahtalar matematik ve geometri öğretmenlerinin işlerini kolaylaştırmaktadır. Öğretmenlik mesleğini 35 yıldır icra eden Kemal-2 bilgisayarlı eğitimin öğretici olabileceği düşüncesine tamamen karşı olmasına rağmen akademik başarı düzeyi yüksek sınıfında etkileşimli tahtayla bir derste daha hızlı ve daha fazla matematik ve geometri sorusunu öğrencileriyle birlikte çözme imkanına sahip olduğu için memnun olduğunu ifade etmektedir. Zaman kaybını önlediği için etkileşimli tahtalar verimli görülmektedir. Ancak akademik başarı düzeyi düşük lisede görev yapan 7 yıllık mesleki deneyime sahip ve akıllı telefonunu daha aktif kullanan Arzu-3 için durum farklılaşmaktadır. Araştırmacı tarafından Arzu-3'nun sınıfın dikkatini toplayamadığı ve negatif-pozitif sayıların toplanması gibi basit matematik işlemlerini bile açıklamadan 11. sınıf düzeyindeki matematik problemlerini çözemediği gözlenmiştir. Böyle olunca başarı düzeyi yüksek lisede öğretmen bir derste 10-12 adet matematik soru çeşidi açıklayabilirken başarı düzeyi düşük bu sınıfta Arzu-3 en fazla 3 soru gösterebilmektedir. Böyle olduğu için etkileşimli tahtayı kullanarak PDF üzerinde hızlı işlem yapmak yerine beyaz tahta ve tahta kalemiyle işlemin her aşamasını anlatarak ders işlemektedir. Etkileşimli tahtanın akademik başarı düzeyi düşük liselerde daha az işlevsel olduğu gözlenmiştir. 


\section{Kitap vs Çevrimiçi Kaynaklar}

Öğrencilerin gerek gündelik hayatlarında gerekse sınıf etosunda bilişim teknolojileriyle yakın temaslarının ders çalışırken ve ödevlerini yaparken kesintiye uğramadığı söylenebilir. Öğrenciler ders çalışırken, ödev yaparken ya da ders dışında bir şeyi merak ettiklerinde kitaplara başvurmak yerine internet taraması yapmayı tercih etmektedirler.

Çalışma grubunun içinde az sayıda öğrenci ödevini hazırlarken kitaplardan faydalandığını söylemiştir (Alper-3, Bilal-3, Leyla-4, Nevin-4, Melek-4). Diğer öğrenciler özellikle kolay ve hızlı olduğu için internet taraması yaparak ödev hazırladıklarını ifade etmiştir. Çok azı (üç) evlerinde bir kitaplık olmadığını söylese de çoğunluğu özellikle ansiklopedilerden ve yardımcı ders kitaplarından oluşan kitaplıklarının olduğunu belirtmiştir. Bununla birlikte ödevlerini hazırlarken "vakit kısıtlı olduğu için internet daha kolayıma geliyor" diyen Elif-1 gibi ödevlerini bir an önce bitirmek için hazır bilgi içeriklerine çevrimiçi ulaşmaktadırlar. Çünkü Hatice-1'nin itiraf ettiği gibi kitaplarda bilgiye ulaşmak için vakit vermek gerekmekte, karıştırmak, okumak ve ödev için lüzumlu malumatı bir araya getirmek, bütünleştirmek ve düzenlemek gerekmektedir. Halbuki hazır ifade kalıplarına oturmuş bilgiye ulaşmak internet üzerinden çok kolaydır. Öyle ki; kolay ulaşılabilirlik ve hız belirleyici olduğu için özellikle günlük ödevlerde bilgisayarı açmak ve karşısına oturmak bile süreci uzatan bir eylem olarak görülmektedir. Ödev hazırlığında akıllı telefonlarla kurulan yakın ilişki belirleyicidir ve öğrencilerin bilgiye ulaşmakta ilk başvurdukları araç telefonları olmaktadır.

İnternet taramasıyla ve aktarma yoluyla yapılan ödevin öğretici olmadığının öğrencilerin de farkında olduğu ifadelerinden anlaşılmaktadır. Çiğdem-1 "ilk önce böyle çok basit, doğru cevabı direk bulabileceğim bir şeyse, yani ezber gibi, onu direk internetten yazıp alıyorum. Yoksa böyle uzun tanım gerektiren bir şeyse kitaplarıma başvuruyorum” diyerek kitaptan öğrenmeyi farklı konumladığını işaret etmektedir. Zira öğrenciler aslında çalışırken kitaplardan faydalanmaları gerektiğini düşündükleri halde hızlı ve kolaylığını bahane ederek çevrimiçi kaynaklara gitmektedirler. Buna rağmen ve internet taramasıyla elde ettikleri bilginin yanlış çıktığı durumlar yaşanmasına rağmen öğrenciler çevrimiçi elde ettikleri bilginin sağlamasını başka çevrimiçi kaynaklara bakarak sağlamaktadırlar. Bir bilginin birçok web sitesinde tekrarlanıyor oluşu, öğrencilere göre, o bilginin doğruluğunu gösterebilmektedir.

Ders kitaplarının dışında kitap okuyup okumadıklarını sorduğumuzda on beş öğrenci olumlu cevap vermiştir; ancak hangi kitapları okuduğunun sorulmasıly çoğunun öğretmenlerinin ödev olarak okumalarını istediği kitapları kastettikleri anlaşılmıştır. Sadece dört öğrenci (Turgut-2, Kübra-2, Elif-1, Ekrem-1) farklı kitaplar okuduklarını ifade ederken on bir öğrenci hiç kitap okumadığını net bir şekilde söylemiştir. Kitapların sıkıcı, kalın ve karışık olduğuna dair serzenişler bu soruların cevaplarında da yer almıştır. İki öğrenci ise hikâye yazma ve okuma uygulaması bulunan bir siteden (Wattpad) kısa hikayeler okuduklarını söylemiştir.

Öğrencilerin ellerinde hazır bulunan akıllı telefonlarını günbegün daha fazla çevrimiçi hale gelen kitaplara ulaşmak için kullanmamalarının sebebi ise başlı başına araştırma konusudur. $\mathrm{Bu}$ duruma dair bizim yaptığımız sorgulamada öne çıan sebep ise akıllı telefonların kendine has 
etosuyla ilgilidir. Şöyle ki; akıllı telefonlarla en fazla sosyal medya hesaplarına ulaşılması, telefon oyunlarının oynanması ve kısa mesajlarla iletişim kurulması bu aygıtların kitap okuma rolünü geride bırakmaktadır. Anlık değişimleri içeren, eğlendirici, basit ve zorlayıcı olmayan içerik akıllı telefonların öncelikli kullanım amacını oluşturmaktadır. Bu sebeple Cezmi-3 telefonu eline aldığında öncelikle aklına "oyun” geldiğini söylerken Fatih-1 kitabın verdiği farklı hissi elektronik aletlerde bulamadığının altını çizmektedir ve diğer amaçlarla kullanmaya alışık olduğu aletleri kitap okumak gibi ciddi bir iş için kullanamadığını ifade etmektedir.

Akıllı telefonların ve bilgisayarların bu etosunun yanı sıra iletişim ve web bağlantısı gibi çoklu işlevinin bulunması da öğrencilerin dikkatlerini okudukları metinde toplayarak metnin ana temasını derinlemesine anlamalarını zorlaştırmaktadır. Öğrenciler dijital okumalarda dikkat dağınıklığı ve odaklanamama sorunu yaşadıklarını belirterek dijital öğrenmenin kalıcı olmadığını ve metnin bütünü yerine merak ettikleri kısımları okuduklarını ifade etmektedirler. Ayrıca özellikle telefonlarından kitap okurken "bildirimlerin" dağıtıcı ve metinden koparıcı etkisi olduğunu vurgulamaktadırlar. Diğer taraftan bu durum onların ekrandan basılı metne dönmelerini sağlamayarak "ellerinden telefonu bırakamadıkları" bir kısır döngünün içinde kendilerini bulmalarına sebep olmaktadır.

Kitaptan uzaklık hissi, öğrencilerin kütüphaneye gitme alışkanlıklarına da yansımaktadır. Bir halk kütüphanesine üye olmak suretiyle düzenli kitap okuyan Kübra-2'nın dışında kütüphaneyle sürekli ilişkisi olan öğrenci bulunmamaktadır. Nadiren ders çalışmak için ya da proje ödevlerini hazırlamak için kütüphaneye gittiğini ifade eden öğrencilerin yanı sıra sessiz olduğu için bazen ders çalışmak amacıyla okul kütüphanesini kullandığını söyleyen öğrenciler mevcuttur.

Diğer taraftan öğrencilerin kitapla ilişkilerinin zayıflamasının tek sebebinin bilişim teknolojileri olduğu iddia edilemez. 11. seneden itibaren merkezî üniversiteye geçiş sınavına hazırlık çalışmalarının da öğrencilerin kitap okumaktan uzaklaşmalarında etkili olduğu söylenebilir. Çünkü, bu sınavın test temelli oluşu okul müfredatının şekillenmesinde etkili olduğu gibi daha fazla düşünmenin ve öğrenmenin tahrik edilmesiyle ortaya çıkan kitap okuma alışkanlığının körelmesinde de etkili olabilmektedir. Ancak test temelli çalışmanın kitap okuma alışkanlığı üzerinde etkili olan en önemli sonucu, sorulara alışkanlık kazanmak adına öğrencilerin bütün vakitlerini soru çözmeye hasretmelerinin gerekli olmasıdır. Kitap okuma alışkanlığına sahip olduğunu belirten öğrencilerden Kübra-2 ve Ekrem-1 liseye başladıktan sonra bu sebeple kitap okumaya vakit bulamadıklarını söylemektedir. Edebiyat öğretmeni Fehmi-1 de lise birinci sınıfta öğrencileri okumaya teşvik ettiklerini ve bunun karşılı̆̆ını da gördüklerini, ancak sonraki sınıflarda edebiyat dersinde bile üniversiteye geçiş sınavına hazırlık çalışmalarının yoğunluğuyla öğrenciyle kitap eksenli kurulan ilişkilerinin koptuğunu vurgulamaktadır.

\section{Bilginin Tek-tipleşmesi}

Bilişim teknolojilerinin eğitim-öğretim faaliyetinin birçok yönünde etkin olmasıyla birlikte kitabın öğrencilerin hayatındaki yeri değiştiği gibi içeriğinin dijitalleşmesi de eğitim-öğretimi farklı boyutlarıyla etkilemektedir. Çalışmamızda tespit ettiğimiz en önemli sonucu bilginin tek-tipleşmesidir. 
Gerek ders içeriklerini videolar halinde sunan EBA’nın yaygınlık kazanmaya başlaması, gerek sayılı Youtube kanalının ürettiği çevrimiçi kaynaklar, gerekse öğrencilerin yardımcı kaynaklar olarak başvurdukları web siteleri bilgi tekelleri olma yolundadır. Bu kanallar bilgiyi dijitalleştirirken aynı zamanda tek-tipleşmesi sonucunu da doğurmaktadır.

EBA videolarının izletildiği dersler arasında coğrafya, tarih, kimya, biyoloji, fizik, edebiyat, dil anlatım, yabancı dil, matematik ve geometri öne çıkmaktadır. EBA tarafından hazırlanan videolarla yapılan dersleri ne öğrenciler ne de öğretmenler yeterli bulmaktadır. Enes-1 video izletilen ders için "metni ekranda takip edemem. Dil anlatım hocamız video açıyor, bazı arkadaşlarımız uyuyor video açtığında, bazıları konuşuyor sessizce" demektedir. Video izlenirken ışıların kapatıldığı, perdelerin çekildiği gözlemlenen sınıf ortamı için Hatice-1 "İnsanın uykusu geliyor, kapatıyoruz ışıkları daha iyi gözüksün diye, akıyor gidiyor, insanın uykusu geliyor. Herkes sessizleşiyor... Ya da en arkada oturunca falan gözükmüyor" diyerek ekrandan akan metnin yakalanmasının zorluğunu işaret etmektedir.

Bu sebeple öğretmen ve öğrenciler EBA videolarının tek başına yeterli olmadığı ve dersi destekleyici materyaller olarak kullanılabileceği görüşündeler. EBA videoları ders konularının anlatılması konusunda faydasız görülürken coğrafya gibi derslerde üç boyutlu şekillerin görülmesinde ya da fizik, kimya gibi derslerde deneylerin izlenmesinde bu videoların etkili olduğu görüşü hâkim. Örneğin kendisinin görsellerle daha iyi öğrendiğini söyleyen Taner-2 gibi Hatice-1 de okurken zihninde canlandıramadığı nesneleri görsellerle daha iyi kavradığının altını çizmektedir. Bununla birlikte deneylerin laboratuvarların eksik kaldığı okullarda EBA videolarıyla gösterilmesinin faydalı olduğu kabul edilse de öğretici ve kalıcı olması bakımından gerçek bir deneyimin yerini tutmasının imkânsız olduğu da ifade edilen gerçekler arasında yer almaktadır. Örneğin daha önce bir özel okulda eğitim gören Sinan-2, karşılaştırma yapabildiği için, laboratuvarda yaptı̆̆ deneylerin daha kalıcı ve öğretici olduğunu söylemektedir.

Diğer taraftan EBA videolarının dersliklerde yer edememesinin asıl sebebi bilgiyi tek-tipleştirmesidir. Ülkedeki bütün okulların aynı aşamasındaki öğrencileri için tek bir video içeriği üretilmektedir. Böylece dijitalleşen bilgi sınıfın gerçek düzeyiyle nadiren uyumlu olmaktadır. EBA ders videoları akademik başarısı yüksek liselerin öğretmenleri ve öğrencileri tarafından kolay ve basit bulunurken akademik başarısı düşük liselerde zor ve karmaşı görülmektedir. İki tür lisenin gerek yöneticileriyle yaptı̆̆ımız yapılandırılmamış görüşmelerde gerek öğretmen odalarında öğretmenlerle yaptığımız genel sohbetlerde ortak kanaat, EBA videolarının standardının sınıfların düzeyiyle uyumsuzluğudur. Akademik başarı düzeyi düşük lisede matematik öğretmeni Arzu-3 bu ders için hazırlanan EBA videolarının öğrencilerinin seviyesinin çok üstünde olduğunu ifade ederken ders kitabındaki konu anlatımının bile öğrencileri tarafından anlaşılmadığını ve bu sebeple daha basit yardımcı kaynaklar kullandığını söylemektedir. Akademik başarı düzeyi yüksek lisenin matematik öğretmeni Kemal-2 ise bu videoların basit kaldığını ve kendi öğrencilerine beş dakikada anlatarak geçtiği konuları bu videolarla anlattığında iki saate ihtiyaç duyulacağını vurgulamaktadır. Dolayısıyla dijital içeriğin öğrenci merkezli eğitimi desteklemesi beklenirken öğrencilerin ve sınıfların çeşitliliğini ihmal eden ulusal bir tek-tiplilik oluşturduğunu söyleyebiliriz. 
EBA videolarına alternatif gibi görülen Youtube videoları ilk bakışta söz konusu tek-tipliliği aşan içerikler gibi görünmektedir. Zira EBA videolarını izlemeye hevesli görünmeyen öğrencilerin neredeyse hepsi (İsmail-3, Arda-3 hariç) ders çalışırken Youtube videolarını izlediklerini ifade etmektedir. Feride-1 gibi Youtube videolarını da basit bulanlar olsa da özellikle sayısal dersler için öğrenciler bu videoları vazgeçilmez bulmaktadırlar. Öğrencilere hangi Youtube kanallarını takip ettiklerini sorduğumuzda toplamda üç kanalın ${ }^{7}$ ismini söylemekteler. Böylece sonsuz çevrimiçi kaynakla muhatap olduğunu düşünen öğrenciler, üç bilgi tekelinin ürettiği içerikten beslenmiş olmaktadır.

Bilginin dijitalleşerek tek-tipleşmesinin sebebiyet verdiği diğer bir sonuç da eğitim-öğretimin zaman bağlamını yitirmesidir. Öğretim, sınıflarla ve müfredatla sağlanan bir bilgi hiyerarşisine ve derecelendirme özelliğine sahiptir. Ancak bilginin her yerde ve her zaman ulaşılabilir hale gelmesi bu hiyerarşiye zarar vermektedir. Nitekim öğrenciler, bazen merak ederek bazen de rekabetin verdiği motivasyonla hep daha fazlasına ve daha zoruna ulaşmak amacıyla çevrimiçi olarak ileri kademe ders içeriklerine baktıklarını ifade etmişlerdir. Diğer taraftan merkezi sınavların zorluğu ve bu sınavlara hazırlığın getirdiği yoğun çalışma disiplini de okul hiyerarşisini parçalarken bu durumu kolaylaştıran unsurun bilginin dijitalleşmesi ve çevrimiçi ulaşımın kolaylaşması olduğunu söyleyebiliriz. Örneğin akademik başarısı yüksek lisede ve kendisi de başarılı bir öğrenci olan ve öz bir disiplinle kendisini ders çalışmaktan alıkoymaması için akıllı telefon kullanmayan Ekrem-1 konuları daha iyi kavrayabilmek için çevrimiçi kaynaklardan üst sınıfların ve sonraki derslerin konularını izlediğini ifade etmektedir. Çünkü, ona göre, okul kitapları konuları basit bir şekilde anlatırken sınavlarda çok zor sorular sorulabilmektedir. Bu sebeple çalışma konularının sınırlarını müfredatla sınırlı tutmak mümkün olmamaktadır.

Çevrimiçi kaynakların ulaşılmasının kolay olması sebebiyle öğrencilerin özellikle merak ettiği konular için kitaplar ya da öğretmenlere başvurmak yerine dijital bilgi deposunda arama yaptıkları anlaşılmaktadır. Dijital bilgi deposu, birçok bilgi türünün iç içe geçtiği ve aynı zamanda başı-sonu, öncesi-sonrası olmayan düz bir çerçevede zamansızlaştığı bir kolaj sunmaktadır. Castells (2013, s. 609-610) multimedyanın oluşturduğu kültürü tasvir ederken görsel malzemeden meydana gelen kültürel ögelerin sanal ortamda zamansal bir sıralamaya tabi olmaksızın ortaya çıktığından bahsetmektedir. Böylece anlamlı olaylar kendi iç ritmik, kronolojik tutarlılığını yitirmekte ve muhatabının kendi toplumsal bağlamına dayalı zaman dizimine yerleşmektedir. Bu durumu öğrencinin zamansızlaşan dijital bilgi deposuyla karşı karşıya kalışına uyarladığımızda çevrimiçi kaynakların okulun inşa ettiği sınıf ve müfredat hiyerarşisini parçaladığını söyleyebiliriz.

Bilginin tek-tipleşmesi, siyasi ve ekonomik nüfuz peşinde olan bilgi tekellerinin eğitim-öğretim alanında etkili olmalarının yolunu açmaktadır. Öğrencilerin takip ettiği Youtube kanallarının aynı zamanda kendi ürünlerini pazarlıyor oluşu bu duruma verilebilecek küçük bir örnektir. Eğitim-öğretim içeriğinin dijitalleştikçe ticari şirketlerin bu alanda tekelleşme rekabetleriyle karşı karşıya kalacak olması/kalıyor oluşu da dikkate değerdir.

7 Tonguç Akademi, Şenol Hoca, Hocalara Geldik. 
Bilginin dijitalleşmesinin bilgiyi tek-tipleştirmesine karşın öğrenci merkezli eğitimi destekleyen en önemli unsur ise halen dersliklerde bilginin sesi olmaya devam eden, bilginin zamanla ve kültürel coğrafyayla bağını kuran öğretmenlerdir. Ancak çağımızın iletişim araçlarında yaşanan değişim aynı zamanda bilgiyi de dijitalleştirdiği için öğretmenin bu konumu her geçen gün değişmektedir.

\section{Kolaylaştırıcı Öğretmen}

Bilgisayarlı eğitimi konu eden alanyazını, bilişi̇m teknolojilerinin eğitim-öğretim faaliyetine etkisiyle öğretmenin dersliklerdeki rolünün uzman öğretmenlikten "kolaylaştırıcı" (facilitator) olmaya evrildiğinin altını çizmektedir. Grasha (2002, s. 154) kolaylaştırıcı öğretmeni öğrenciler için birer rehber olarak tanımlamaktadır. Buna göre öğretmen sorular sorarak, öğrencilerin çeşitli seçenekleri keşfetmelerini sağlayarak ve farklı yollar göstererek onları bilinçli tercih yapabilmeleri için ölçütler oluşturmaya yönlendirir. Kolaylaştırıcı öğretmenin öğretim amacı, öğrencilerin bağımsız bir şekilde eyleme geçme, girişkenlik ve sorumluluk alma kapasitelerini geliştirmektir. Öğretmen ile öğrenci arasında gelişmesi beklenen doğal ilişkiye dayanan kolaylaştırıcı öğretmenliğin aksine "uzman" öğretmen öğrencinin ihtiyaç duyduğu bilgi ve uzmanlı̆̆a sahiptir. Öğrencilere ayrıntılı bilgi vermek suretiyle ve onları yeteneklerini geliştirmeye zorlayarak sınıfta kendi uzmanlık statüsünü tahkim eder. Uzman öğretmen bilgi aktarımını ve öğrencilerin iyi öğrenmiş olmalarını öncelerken kolaylaştırıcı öğretmen cevaplara ulaşma süreçlerini göstererek öğrencilerin bilgiye ulaşmalarını sağlamakta ve eğitim-öğretim sürecine öğrenciyi dahil etmektedir.

Çağdaş eğitim araştırmalarının çoğu öğrenci-merkezli öğretimin daha başarılı olduğu savını desteklemektedir. Öğrencinin uzman öğretmenden bilgi almak yerine proje temelli öğrenme yöntemleriyle bilgiye ulaşma yollarını keşfetmesi yeğlenmektedir. Eğitim teknolojilerinin proje temelli ve öğrenci-merkezli öğrenmeyi desteklediğinden hareketle (Condliffe vd., 2017; Grasha, 1994; Niess, 2012) eğitim-öğretim faaliyetinin kalitesi için tercih edildiği görülmektedir. Dolayısıyla sınıfta öğretmenin uzman rolünün kolaylaştırıcı olma yönünde değişmeye başlaması eğitim teknolojilerinin eşlik ettiği paradigmatik bir dönüşümün yansımasıdır. Diğer taraftan gerek sınıflardaki gözlemlere gerekse öğretmen ve öğrencilerle yapılan görüşmelere dayanarak çoğunlukla öğretmen-merkezli öğretimin (Öğretmen Remzi-2'nin edebiyat sınıfı hariç) baskın olduğu söylenebilir. Öğretmenler bunun sebebi olarak öğrenci sayılarını ve müfredatın sınav merkezli oluşunu işaret etmektedir. Şevket-4 ve Nilgün-4’e göre, kalabalık sınıflarda öğrencilerini tam olarak tanıyamamaktadırlar bile. Diğer taraftan Remzi-2'nin benzer sayıdaki sınıfta öğrencilerle etkileşimli işlediği dersler, bu noktada asıl etkenin öğretmenin sınıf yönetiminde tercih ettiği yöntemin ve edebiyat gibi sözel iletişime daha açık ders çeşidinin etkili olduğunu düşündürebilir. Nitekim Şevket-4 eğitim teknolojilerinin tek başına öğrenci-merkezli eğitimi sağlamadığını vurgularken dijital kayıtların kullanıldığı derslerde bile öğretmenin yönlendirici ve bilgisiyle destekleyici işlevi olmaksızın öğrenmenin gerçekleşemeyeceğini söylemektedir. Bu noktada Kemal-2 de sınav sisteminin belirleyiciliğini hatırlatarak müfredatı yetiştirme zorunluluğunun beceri geliştirmeye odaklı öğrenci-merkezli öğretimi uygulamaya engel olduğunun altını çizmekte ve öğretmenin söz konusu müfredatın aktarıcısı olarak merkezî konumunu korumaya devam ettiği kanısını güçlendirmektedir. 
Diğer taraftan öğrencilerin dijital kaynaklara kolay erişiminin onların öğretmenleriyle ve müfredatla ilişkilerini paradigmatik olarak değiştirmeye devam ettiği de söylenebilir. Çalışma grubumuzda öğrencilerin ellerinde kolay ulaşabildikleri dijital bilgi kaynağı olarak akıllı telefonlarının bulunmasının onları dersleriyle ilgili merak ettikleri soruları öğretmenlerine sormak yerine internet kaynaklarında cevap aramaya sevk ettiği gözlenmiştir. Soru sorma ihtiyacı hissettiklerinde, eğer derslikte değillerse, doğrudan çevrimiçi kaynaklara başvurmaktadırlar. Öğretmenine sormak üzere soru sormayı ertelediğini söyleyen tek öğrenci Özlem-1, "internete bakmamaya çalışırım” diyerek bunun için kendini kontrol etmeye çalıştığını vurgulamaktadır. Diğer taraftan soru sorma ihtiyacı hissettiklerinde derslikte öğretmenleriyle birlikte olsalar bile onlara sormak yerine çevrimiçi kaynaklara başvurduğunu söyleyen öğrenciler az değiller (Bilal-3, Yeşim-4, Fatma-4, Zeynep-4, Turgut-2, Zehra-2, Kübra-2, Elif-1, Hatice-1). Öğretmenin cevabını çevrimiçi kaynaklarla teyit eden (Adem-3) olduğu gibi bu kaynaklarda bulamadığında öğretmene başvuranlar da mevcuttur (Ekrem-1).

Ancak çevrimiçi kaynakların bilgiyi tek-tipleştiren özelliğinden dolayı öğrencilerin çoğunlukla buldukları cevaplardan tatmin olmadıkları üzerinde durulması gereken bir durumdur. Öğretmen bilgiyi öğrencinin akademik seviyesine uyarlamaktadır. Bu sebeple Elif-1 çevrimiçi kaynağı okuyup anlamadığında öğretmenine sorduğunu söylemekte ve öğretmenin kendilerine daha anlaşılır bir şekilde anlattığının altını çizmektedir. Taner-2 ve Selma-2 da çevrimiçi kaynaklarda kendi seviyesine göre cevap bulmakta zorlandığını itiraf etmekle birlikte Selma-2 sayısal derslerle sözel dersler arasında ayrım yapmaktadır. Sözel derslerde çevrimiçi kaynaklardan faydalanmanın daha mümkün olduğu görüşünü Duygu-1 da paylaşmaktadır. Ancak Fatih-1 aksine sözel derslerde öğretmenin gerekliliğinin altını çizmektedir. Bu durum da çevrimiçi kaynakların tek-tipliliğine karşın öğrenci ihtiyaçlarının çeşitliliğini tasvir etmektedir.

Video kayıtlarla ya da canlı yayınla yapılan çevrimiçi eğitimi doğrudan öğretmenle yapılan eğitime tercih edip etmeyeceklerini sorduğumuzda öğrencilerin çoğu öğretmen lehine cevap vermiştir. Az sayıda video kaydı tercih edenlerin akademik başarı seviyesi düşük liselerin öğrencilerinden (Adem-3, Fatma-4, Leyla-4, Nevin-4, Yeşim-4, Mehmet-3) oluşması dikkat çekmektedir. Bu öğrenciler iyi hazırlanmış video kayıtlarını dersleri iyi anlatamayan öğretmenlere tercih edebileceklerini söylemektedirler. Nitekim akademik başarı seviyesi yüksek lisenin öğrencisi Taner-2 ve Ebru-2 aynı sebeple çevrimiçi eğitimi yetersiz bulmakta ve okul öğretmenlerinin dersleri kendi seviyelerine uyarlayarak daha derin öğretici olduklarını ifade etmektedir. Akademik başarı seviyesi düşük liselerde öğrencilerin öğrenme performanslarının düşüklüguünün yanı sıra meslek deneyimi az öğretmenlerin istihdam edilmesinin de öğrencilerin öğretmenlerinin yetkinliğiyle ilgili olumsuz düşüncelere sahip olmalarında etkili olduğunu düşünebiliriz. Bu liselerden birinde matematik öğretmeni olan Arzu-3 öğrencilerin çalışma gayreti olmadığ için kendisini verimli hissetmediğini ve uzaktan eğitimle öğrencilerinin akademik başarı düzeyinin de örgünde olduğundan daha düşük olmayacağını söylemektedir. "Çalışmayan için kaynağın ne olduğunun pek önemi yok” diyerek saatler boyu ders anlattığı için performansının düştüğünü ve uzaktan eğitim ile öğrencilerin daha iyi öğrenebileceğini kaydetmektedir. 
Dersleri öğretmenden dinlemek istediklerini söyleyen öğrenciler ise kahir ekseriyettedir. Ancak sadece dört öğrenci (Mehmet-3, Bilal-3, Taner-2, Sedat-2) öğretmenin farkını daha iyi öğretmesi üzerinden temellendirmektedir. Öğrenciler açısından öğretmenin öğretim faaliyetindeki konumunu korumasının en önemli gerekçesi sınıftaki düzen ve disiplini sağlayabilmesi ve sevgi ilişkisi çerçevesinde ilişki kurabilmesidir. Bu bağlamda öğrenciler canlı olarak muhatap olmadıkları sanal kişilerin kendileri üzerindeki otoritelerini hissetmedikleri için sınıf düzeninin ve disiplininin sağladığı yoğunlaşmayı başaramadıklarını ifade etmektedirler. Derslikteki öğretmen otoritesi, çevrimiçi öğretmenin aksine, öğrencilerin (Hatice-1, Cezmi-3, Taner-2, Yeşim-4, Elif-1, Demet-1, Çiğdem-1, Ekrem-1, Enes-1, Talha-3) eğitim-öğretim faaliyetini ciddiye almalarını ve sürdürmelerini sağlamaktadır.

Öğretmenle iletişime geçebilmek ve ona soru sorabilmek ise öğrencilerin öncelikle önemsedikleri bir sınıf faaliyetidir. Ancak çevrimiçi eğitim-öğretim faaliyetinin etkileşimli olma imkânı kendilerine hatırlatıldığında verdikleri cevaplar, öğretmenle iletişimi bilgi aktarımının ötesinde duygusal ihtiyaçtan dolayı önemsediklerini ortaya koymaktadır. Öğrencilere göre öğretmenler dersi anlayıp anlamadıklarını onlar ifade etmeseler bile fark etmektedir ve ders konusunu bu duruma göre açıklamaktadırlar. Öğretmenle kurulan sevgi temelli ilişki, dersin anlaşılmasını kolaylaştırmaktadır.

Öğretim faaliyetinin sevgi temelinde kolaylaşmasının yanı sıra öğrencilerin öğretmenlerini sadece "öğreten” olarak değil "eğiten” olarak da görüyor oluşu öğretmenin sınıf içindeki iki boyutlu ve vazgeçilmez konumuna dair ipucu vermektedir. Zira hal ve davranışlarını örnek aldıkları öğretmenlerinin olup olmadığ ${ }_{1}$ sorulduğunda öğrencilerin çoğu, özellikle başarılı ders anlatan ve öğrencileriyle özel bir iletişim kurarak onları özel hayatlarında daha başarılı ve ahlaklı olma yönünde teşvik eden öğretmenlerini rol-model ${ }^{8}$ olarak seçtiklerini ifade etmektedirler. Fatih-1, rol-model olarak gördüğü fizik öğretmeninin sevgi dolu yanını vurgulayarak "disiplini çoğu hoca gibi bağırarak değil de bizi fazla severek yapıyor. Derste de hepimize böyle 'yakışıklı' diyor, kızlara 'güzellik' falan diyor. 'Ne kadar güzelsin' falan diyor. Böyle övgüler veriyor' demektedir. Bu sevgi temelinde yaklaşım öğretmenin öğretim faaliyetine yönelik olumlu bakışı da beslemektedir: "Sonra eğlenceli bir şekilde dersi işliyor. Örnek veriyor. Sayısal bir ders olmasına rağmen fizik, çoğumuz sadece formüllerden ibaret biliriz. Hoca onu bize daha çok gözümüze aşina ederek anlatmaya çalışıyor.” Duygu-1 ise matematik öğretmeninin kendisi için rol-model olma sebebini, "ders dışında çok fazla bilgisi var yani hepsinin öyle de ne bileyim hani belki iletişimi diğer hocalardan biraz daha farklı o yüzden” şeklinde açıklarken öğretmeninin mesleki başarısının öğrencinin gözündeki değerini tasvir etmektedir. Demet-1 aynı öğretmenin kendisi için de rol-model oluşunu "bize gerçekten iyi insan olmayı da bence bazen aşılıyor ve nasıl ders çalışmamız gerektiğini de...” diyerek ve Çiğdem-1 ise bu öğretmenin dersin dışında hayatlarını nasıl düzenleyeceklerine dair nasihatlerde bulunduğunun altını çizerek öğretmenin rol-model olarak öne çıkışını izah etmektedir.

8 Merton (1968, s. 356-357)'a göre "rol-model” belirli beceri ve davranışları kendisinden öykünme yoluyla edindiğimiz kişidir. Bu kişi bize belli bir beceriyi nasıl hayata geçireceğimizi ve hedefe nasıl ulaşacağımızı davranışlarıyla gösterir. Rol-model, aynı zamanda bize bir hedefin ulaşılabilir olduğunu göstererek başarı için ilham kaynağı olur (Morgenroth, Ryan \& Peters, 2015, s. 467). 
Dört okulda görüştüğümüz öğrencilerin rol-model olarak belli öğretmenleri işaret ettikleri vurgulamamız gereken başka bir husustur. Bunların arasında özellikle akademik başarı seviyesi yüksek liselerde görev yapan öğretmenler öne çıkmaktadır. Ancak öğrencilerin rol-model olarak bazı öğretmenleri öne çıkarmasının sebebi, akademik yetkinliğin yanı sıra öğretmenlerin öğrencilerinin akademik başarılarının dışında insanî yönlerini güçlendirmeyi amaçlamalarıdır. Zira iki öğrenci hariç (Ali-3, Ümit-2) öğrencilerin tamamı öğretmenin öğrencilerine "iyi insan” olarak rol-model olması ve onlara insanî hasletleri anlatmasının aslî görevi olduğunu düşünmektedir. Öğretmenlerin tümü de insanî değerlerin açık ya da gizli müfredat ile öğrencilere aktarmayı, birer "eğitmen" olarak temel amaçları olarak görmektedir. Bilginin ve öğretimin dijitalleşmesi ise bu değer aktarımı işlevlerinin zarar görmesi anlamına gelmektedir. Dijital bilginin aktarımında bile öğretmenin rehberliğinin kaçınılmaz olduğu ortadayken eğitmenliğin ihmal edilmesinin sakıncalarını tasvir etmektedirler. Remzi-2 öğretmenin eğitmenliğinin bilgiyle beraber "perspektif" vermesiyle ortaya çıktığını vurgulamaktadır. Bu yüzden sadece bilgi aktarmayı hedefleyen sayısal derslerin dijitalleşmesi muhtemel olsa da sözel dersler için dijital kaynaklar sadece yan ürün olabilirler. Ancak matematik öğretmeni Kemal-2 sayısal derslerde bile insan ilişkilerini deneyimlemek şeklinde değer aktarımının devam ettiği uyarısında bulunmaktadır. Diğer taraftan sınav merkezli mevcut müfredatın öğretmeni sadece bilgi aktarıcısı haline getirdiğini de hatırlatmaktadır. $\mathrm{Bu}$ sebeple bu değişimin handikaplarını eğitim felsefesinin temellerinin altını çizerek eğitimin sadece öğrenciye bilgi yüklemek olmadığını vurgulamaktadır.

Öğrencilerin kahir ekseriyetle görüş birliği yaptığı diğer bir konu, "iyi insan" olmakla "iyi meslek” sahibi olmayı birbiriyle ilişkili görmeleridir. Sadece iki kişi (Cezmi-3, Leyla-4) önceliği iyi meslek sahibi olmaya verirken iyi insan olmanın daha önemli olduğunu ya da iyi insanın zaten mesleğini iyi bir şekilde icra edeceğini söyleyenler çoğunluktadır. Bu durum öğrencilerin akademik başarısıyla öğretmenle kurdukları yakın ve sevgi temelinde iletişimin ilişkili olduğunu göstermektedir. Öğretmenin rol-model olma imkanını sağlayan bu ilişkiselliği ortaya koyan diğer en önemli bulgu ise öğrencilerin yaşadıkları kişisel sorunları paylaşacak kadar kendilerini öğretmenlere yakın hissedebilmeleridir. En az bir öğretmene karşı bu tür bir yakınlık hissi taşıyan öğrencilerin sayısı kendisini herhangi bir öğretmenle yakın hissetmeyenlerden daha fazladır. Rol-model olarak öğrenciler tarafından ismi telaffuz edilen edebiyat öğretmeni Remzi-2'nin derslikte öğrencileriyle kurduğu yakın iletişim, öğrencilerin kurduğu akademik başarı-yakın iletişim ilişkiselliğini doğrulamaktadır. Bu durum öğretmenlerin "eğitmenlik" rollerindeki başarılarının “öğretmenliklerini” güçlendirdiğini göstermektedir.

\section{Eğlendirici Öğretmen}

Araştırmamızın bulguları arasında ortaya çıktığını gözlediğimiz diğer bir durum öğretim materyallerinin, eğitim-öğretim faaliyetinin ve öğretmenin eğlendirici olması gerektiği yönündeki artan beklentidir. Bu durum, dijitalleşmenin bilgi türünde meydana getirdiği değişiklikle açıklanabilir. Öğretim içeriği daha fazla görsellerle bezenmekte ve dikkat çekici olması için grafik tasarımla, animasyonlarla estetize edilerek daha hareketli ve dikkat çekici hale getirilmektedir. İçeriğin dikkat çekici olması kadar eğlendirici olması da öğrencilerin tercih sebebidir. 
Bilgi içeriğinin dikkat çekici ve eğlendirici bir karakter kazanması televizyonun bir bilgi aktarma ve öğretim aracı olarak görüldüğü yıllara kadar geri götürülebilir. Postmann’ın (1979) televizyonun hayatımıza girmesiyle bütün öğrenim içeriğinin eğlenceli olmaya odaklandığı tespitine dayanarak bilgi türünün televizyonun öğretim kanalı olmasıyla eğlenceli olma yönünde değişmeye başladığını söyleyebiliriz. Bu durum çalışma grubumuzdaki öğrencilerin EBA ders videoları yerine You Tube videolarını tercih etmelerinin ana sebebi olarak ortaya çıkmaktadır. Öğrenciler EBA videolarını sıkıcı, soğuk ve basit bulurken You Tube videolarını rahat, eğlendirici, işlevsel ve öğretici olarak tasvir etmektedirler. Bilal-3 EBA’da ders anlatan öğretmenleri okuldaki öğretmenlerine benzetmekte ve You Tube videolarını daha eğlenceli bulmaktadır. Dijital bilgi kaynaklarının görsellerle çeşitlenmiş bol seçeneği karşısında öğrenciler okul derslerini basit, tekdüze ve düz bulmaktadır. Bu durum öğretmenleri her geçen gün daha fazla eğlendirerek öğretme baskısı altına almaktadır. Eğitim teknolojilerine yatkın öğretmenler aynı sebeplerle sınıflarında çeşitli görselleri ve videoları kullanmak zorunda olduklarını ifade etmektedir. Edebiyat öğretmeni Fehmi-1 EBA videolarının yetersiz ve sıkıcı olduğu gerekçesiyle farklı web kaynaklarını dersinde göstermektedir. EBA videoları da eğlendirerek öğretme iddiasında olmakla birlikte, bazen de amacı eğlendirmek olmasa da, Fehmi-1'ye göre "zayıf bir komedi gibi” olduğu için öğrenciyi tatmin etmemektedir.

\section{Tartışma, Sonuç ve Değerlendirme}

Dijitalleşme, eğitim-öğretim aktörlerini hem gündelik hayatlarında hem sınıfta etkilemektedir. Akıllı telefonlar üzerinden eğitim-öğretim materyallerini içeren dijital kaynaklarla ilişki süreğen hale gelmiştir. Ayrıca gerek EBA gerek You Tube gibi özel dijital kanallar eğitim-öğretim materyalinin tek-tipleşmesine sebep olmaktadır. Bu bakımdan dijitalleşmenin öğrenci-merkezli eğitimi desteklediği savı bu araştırmada yanlışlanmaktadır.

Dijitalleşme öğretmenin eğitim-öğretim faaliyetindeki rolünde, öğrencinin öğretmen ve kitapla ilişkisinde değişimi getirmiştir. Bu değişimin en önemli fenomenlerinden biri bilginin tek-tipleşmesidir. Bilginin dijitalleşmesiyle bütün öğrencilerin aynı bilgi içeriği ile muhatap olmaya başlaması elbette yeni bir olgu değildir. Milli eğitim sistemlerinin kurulması ve kitabın eğitim materyali olarak resmi müfredatın taşıyıcısı olması da bilgi içeriğinin ve öğretim metotlarının tek-tipleşmesi anlamına gelmektedir (Ong, 2003, s. 159). Bununla birlikte kitabın sınıftaki sesi olarak öğretmen değişik düşünceleri ve yorumları dillendiren olarak çeşitliliği sağlayan ve dolayısıyla bilgiyi eğitim ortamına uyarlayan aktördür. Dijital kaynaklar ise ilk bakışta bilgi tekelini kırıyor ve çeşitliliği sağlıyor gibi görünse de, a) bilginin imajlarla aktarılıyor oluşu, b) ekonomik çıkar yüklü oluşu söz konusu çeşitliliği sınırlayarak tekelleştirme ve tek-tipleştirme özelliğini öne çıkarmaktadır.

Özellikle imajlar aracılığıyla dijitalleşen bilgi içeriği, planlı bir kurguya dayalı olmasından dolayı kitaplara nispetle gerçeklikle daha mesafelidir. Çünkü bu kurguda imajın/dijital içeriğin kendisi yerine bunu kurgulayanın gerçekliği öne çıkmaktadır. Ellul'ün (2004, s. 186) dediği gibi “... imaj, 'gösterilen' şeye -yani gerçekliğe- açık bir benzeyişe (resemblance) dayanır” ancak gerçekliğin kendisi değildir. Bu sebeple dijital bilgide yorum çeşitliliği kurgulayanın tekelindedir ve bir öğretmene ihtiyaç duyulmaksızın öğrenciye aktarılabilir. 
Bu araştırmada dijitalleşme bağlamında liseler arasındaki akademik başarı seviye farkıyla ortaya çıan çeşitlenme gösterilmiştir. Dijitalleşen öğretim içeriği öğrencilerin akademik seviyeleriyle nadiren uyumludur. Diğer taraftan dijitalleşen bilgi içeriği aynı zamanda alt yapı yatırımları ve eğitim materyalleri ile yeni endüstrinin önemli bir ticaret metası haline gelmektedir. Masuda (1990, s. 69) eğitimin dijitalleşerek "endüstri” haline geleceğini ve bilgi endüstrisiyle birlikte eğitim endüstrisinin bilgi toplumunun temelini oluşturacağını öne sürmüştür. Dijital bilgi içeriğinin çeşitli piyasa aktörlerince üretiliyor oluşu Masuda’nın bahsettiği endüstriyel gelişmenin temelini oluşturmaktadır. Şimdi, bu gelişmeyle birlikte dijital içeriğe erişim, ekonomik ve toplumsal sınıflar kapsamında eğitimde eşitsizlik tartışmaları bağlamına yerleşse de konumuz açısından asıl sorunsallaştırılması gereken husus, yüksek maliyetli "kitle eğitiminin” dijitalleştirilerek uzun vadede düşük maliyetli bir "iş koluna” dönüştürülmesi eğilimidir. Bu durum kamu politikaları tarafından dijitalleşmenin teşvik edilmesine sebep olmaktadır. T.C Milli Eğitim Bakanlığı’nın 2023 Eğitim Vizyonu'nda (2018, s. 74) dijital materyallerin ana öğretim materyali haline gelmesinin amaçlandığ belirtilmiştir. Öğretim içeriğinin tamamının dijitalleşmesiyle, çağdaş eğitim sisteminde dijitalleşmenin oluşturduğu eşitsizlikten hareketle, kitle eğitimini sağlayan çok sayıdaki okul ile elit eğitimini sağlayan az sayıdaki okul arasında oluşması muhtemel derin uçurum öngörülebilir. Bu durum çağdaş dünyada yaşanan bilgi teknolojilerine sahiplik düzeyinde oluşan eşitsizliklerden daha derin bir toplumsal eşitsizliğe sebep olabilir. Kitle eğitiminde dijital ve tek-tip öğretim içeriği, eğitimde fırsat eşitliği çerçevesinde de sorunsallaştırılmalıdır.

Feenberg (2002, s. 122) teknolojik dönüşümün bu tarihi aşamasında teknolojinin geleneksel meslekler gibi öğretmenliği de boşa çıkarması ihtimali üzerinde durmaktadır. Bilgi toplumunda öğretmenin rolüne ilişkin değişim, elbette sadece dijitalleşmenin yarattığı etkiyle açılanamaz. Üretim süreçlerinde, eğitim-piyasa ilişkilerinde ve düşünsel alanda yaşanan değişimin eğitimde bütüncül paradigmatik bir dönüşüme sebep olduğu görülmektedir. Dijitalleşme bu paradigmatik değişimin hem sebebi hem sonucu olarak iki boyutuyla karşımıza çıkmaktadır. Eğitim sistemi, öncelikle üretimin otomasyonlaştığı piyasaya kalifiye kadro yetiştirmek zorundadır. Bu sebeple öğrencilerin dijital becerilere sahip olmasını amaçlamaktadır. İkincisi, gerek eğitim-öğretim faaliyetinin daha etkin ve başarılı olacağı savından hareketle gerekse -bahsi geçtiği üzere- kitle eğitimini kolaylaştırdığı gerekçesiyle öğretim süreçlerinin dijitalleşme yönünde hızla geliştiği görülmektedir. Bu yönelimi Gur ve Wiley (2007) paketlenip dağıtılan bilgi aktarımına indirgenmesi sonucunu doğurduğu için eğitimin "nesneleştirilmesi” olarak nitelemektedir. Çünkü özellikle öğretme eylemi dijitalleşme ile birlikte bilgi aktarım sürecine, dersler ise bilgisayar yazılım paketine dönüşmektedir. Sonuç olarak dijitalleşme öğretmenler üzerindeki bürokratik denetimi artırırken onların öğretme eylemindeki etkilerini azaltmakta ve onları "vasıfsızlaştırmaktadır" (Buyruk, 2015, s. 182-186).

20. yüzyılın ikinci yarısından itibaren meslekî yeterliliklerin artmasıyla okulların her geçen gün daha fazla meslekî uzmanlık bilgisini öğretme zorunluluğuyla karşı karşıya kalmasına sebep olmuştur (Bilton vd., 2009, s. 290). Bu durum okullara müfredatın sınav merkezli olması ve okul faaliyetinin eğitimden daha fazla öğretime odaklanması olarak yansımıştır. Eğitim ve öğretimin öğretim lehine birbirinden kopmaya başlaması ve öğretimin yeni teknolojilerle gerçekleştirilebi- 
leceği düşüncesi öğretmenin konumunu tartışmalı kılmaktadır. Skinner’in “insan olmanın gereklilikleri” şeklinde tanımladığı eğitim içeriği, pozitivist ve değerden arındırılmış yapısıyla hali hazırda tanımlı sağlam bir zemine sahip olmadığı için dijitalleşme ile birlikte boşa çıkacağı tartışması da zeminsiz yürümektedir. Öğretmenin son tutamak olarak yapıştığı "kolaylaştırıcılık" rolü ise öğretimle sınırlı kalmaktadır.

Öğrenme kuramlarının eğitim teknolojileriyle öğrenme ile ilgili geliştirdikleri açıklamalarda gördüğümüz gibi bu açıklamalar en fazla öğretimin sadece makine ile gerçekleşmesi durumuna yoğunlaşmaktadır. Öğrenmeyi toplumsal ilişkiler çerçevesinde konumlayan ve dolayısıyla öğretmenin rolünün altını çizen sosyo-kültürel öğrenme yaklaşımı hiç şüphesiz bu kuramların içinde öğretimin sosyolojik boyutunu en fazla açıllayandır. Ancak öğretime kültürel yaklaşım çoğunlukla öğretimin kişilerarasıllı̆ına vurgu yaparak yüz yüze eğitimi idealleştirirken (Crook, 2002, s. 27) günümüzde yaygın olarak görülen "karma eğitim” modeline ilişkin yetersiz kalmaktadır.

Dijitalleşme ile geleneksel eğitim-öğretim faaliyeti köklü bir değişikliğe uğramakla birlikte güçlü ve donanımlı öğretmenin dijital kaynaklara rağmen ya da onlarla birlikte eğitim-öğretim faaliyetinin belirleyici aktörü olmaya devam ettiği kaydedilmelidir. Gözlemlerimizde öne çıkan iki öğretmen tipolojisi bu kanaati pekiştirmektedir. Edebiyat öğretmeni Remzi-2 sınıfta grup dinamiğini dikkate alan "koç" ve öğrencilerinin özel sorunlarını sınıf dışında dinleyen ve çözüm üreten "psikolog" tipolojisinde bir öğretmendir (Karadağ ve Dulay, 2017, s. 116, 87). Öğrencilerin neredeyse hepsinin derse katılımını sağlamaktadır. Öğrenciler onun dersinde rahatça fikirlerini beyan etmektedir. Canlı, hareketli, motive edici ve giyim tarzıyla, kullandığı dille gençlere yakın görünmektedir. Kural koymamasına rağmen (örneğin sınıfa girdiğinde öğrenciler ayağa kalkmıyor ve dersinde öğrencilerin cep telefonları masalarının üzerinde kalabiliyor) yapıcı bir otorite anlayışına sahip ve ders düzenini ve ilgisini sürekli hale getirebilmektedir. Öğrenci-merkezli bir eğitim anlayışının olduğu söylenebilir. Matematik öğretmeni Kemal-2 ise sınıfı baskın bir şekilde hissedilen güç ve otoriteyle yönettiği için "gemi kaptanı" ve sınıfta uzmanlığından kaynaklanan güven iklimi oluşturduğu için "uzman” tipolojisinde bir öğretmendir (Karadağ ve Dulay, 2017, s. 141, 225). Her dersten sonra araştırmacıya yeni neslin "dersi kaynatma" eğiliminde olmasından şikâyet etmiştir. Ders anlatırken devamlı kuralları hatırlatmaktadır (sınıfa girdiğinde öğrenciler ayağa kalkıyor ve kendisine güçlü bir sesle "sağ ol" diyerek cevap veriyor). Sınıfta kendisinden başka kimsenin sesi çıkmamaktadır. Öğretmen-merkezli bir eğitim anlayışının olduğu söylenebilir. Diğer taraftan Kemal-2 öğrencilerinin dersle ilgili izin alarak sordukları soruları sabırla cevaplamaktadır. Alanında uzman bir öğretmen olarak öğrencileri tarafından takdir edilmekte ve sevilmektedir. Okul müdürü kendisinden sitayişle bahsetmektedir. Bu iki öğretmenden daha genç olan Remzi-2 özel hayatında yeni teknolojilere daha aşina ve derslerinde de dijital kaynakları kullanırken Kemal-2 hız kazandırdığı için akıllı tahtayı kullansa da dijital kaynakları kullanmamakta ve özel hayatında yeni teknolojilerle mesafeli kalmaktadır. Genç bir öğretmen olan Fehmi-1 de Kemal-2 gibi "gemi kaptanı" tipolojisinde bir öğretmen ve öğretmen-merkezli bir eğitim anlayışına sahip olmakla birlikte hem özel hayatında hem derslerinde yeni teknolojiler ve dijital kaynakları kullanmaktadır. Ayrıca diğer iki öğretmen gibi alanında uzman ve öğrencileri tarafından 
takdirle sevilmektedir. Sonuç olarak yeni teknolojiler eğitim ortamında güçlü öğretmenler tarafından kullanıldığında öğrenci-merkezli veya öğretmen-merkezli eğitim pratiği açısından nötr hale gelebilmektedir ${ }^{9}$. Ayrıca bu güçlü öğretmenler dijital kaynakları kullanırken bile sınıflarındaki eğitim-öğretim faaliyetinin merkezî aktörü olmaya devam ederek "karma eğitim” örneği oluştururken öğretim kuramlarının gerçekliği açıklamadaki yetersizliğini imlemektedirler.

Çağdaş dünyada dijitalleşmede geri dönülemez bir noktaya gelinmiştir. Eğitim-öğretim faaliyetinde de dijitalleşme kaçınılmaz görünmektedir. Ancak bu süreç geleneksel eğitim anlayışını değiştirmektedir. Zira eğitim teknolojileri ve genel olarak dijitalleşmenin doğası eğitim ortamını "bedenden arındırma" (Dreyfus, 2016, s. 61) özelliğine sahiptir. Bir öğretmen dersini videokaset ile kaydetse bile bu kayıt bedeniyle sınıf ortamında gerçekleştirdiği eğitim-öğretimin işbirliği, rekabet, gerilim gibi çok boyutlu ilişki biçimlerini içeren etkileşimi içeremeyecektir. Bedensizlik eğitim-öğretimin doğasını değiştirmektedir. Ancak mevcut uygulamalarda hem eğitim hem öğretimde öğretmen bedenine ihtiyaç duyulduğu görülmektedir ve bu araştırma bunu teyit etmiştir. Bunun sonucu olarak da yüz yüze öğretim ile dijital öğretimin birlikte uygulandı̆̆g "karma eğitim" ortaya çıkmaktadır. Bu sebeple dijitalleşmeyi sadece makineden öğrenme şeklinde tanımlayan kuramsal açıklamalar "karma eğitim”de eğitim ve öğretimin yeniden anlamlandırılması yönünde açılım gerçekleştirmek zorundadır. Çünkü eğitim-öğretimin aktörlerinin bedensellikleri geleneksel eğitimin sürekliliği açısından salt dijital eğitime karşı bir direnç oluşturmaktadır. Bu araştırma kuramsal açıklamaların eğitim-öğretimin "karma eğitim” olarak gerçekleşme durumuna göre geliştirilmesi ve dijitalleşen ortamlarda öğretmenin eğitim ve öğretim rollerinin sahadan alınan dönütlerle yeniden tanımlanması ihtiyacını ortaya koymaktadır.

\section{Kaynaklar}

Bilton, T. vd. (2009). Sosyoloji. Ankara: Siyasal Kitabevi.

Buyruk, H. (2015). Öğretmen emeğinin dönüşümü. İstanbul: İletişim Yayınları.

Castells, M. (2013). Enformasyon çağı: Ekonomi, toplum ve kültür - Birinci cilt: A ̈̆ toplumunun yükselişi. İstanbul: İstanbul Bilgi Üniversitesi Yayınları.

Condliffe, B. vd., (Oct 2017). Project-based learning: A literature review. New York: MDRC Building Knowledge To Improve Social Policy.

Crook, C. (2002). The social character of knowing and learning. Journal of Information Technology in Teacher Education, $10,19-36$.

Crook, C. (2008). Theories of formal and informal learning in the world of web 2.0. Theorising the Benefits of New Technology for Youth, (p. 30-34), University of Oxford \& London School of Economics.

Dreyfus, H. L. (2016). İnternet üzerine. İstanbul: Küre Yayınları.

Ellul, J. (2004). Sözün düşüşü. İstanbul: Paradigma Yayınları.

Feenberg, A. (2002). Transforming technology: A critical theory revisited. New York: Oxford University Press.

Grasha, A. F. (1994). The teacher as expert, formal authority, personal model, facilitator, and delegator. College Teaching, 42(4), 142-149.

9 Bilgisayarlı eğitimin öğrenci-merkezli olma savının her durumda geçerli olmadığını gösteren bir çalışma olarak bkz.: Wang, 2001. 
Grasha, A. F. (2002). Teaching with style: a practical guide to enhancing learning by understanding teaching and learning styles. San Bernadino: Alliance Publishers.

Gur, B.S. \& Wiley, D. A. (2007). Instructional technology and objectification. Canadian Journal of Learning and Techno$\log y, 33(3), 113-136$.

Hatch, J. A. (2002). Doing qualitative research in education settings. Albany: State University of New York Press.

Innis, H. A. (2008). The bias of communication. (Second edition with a new introduction by Alexander John Watson), Toronto, Buffalo, London: University of Toronto Press.

Karadağ, E. \& Dulay, S. (2017). Öğretmen tipolojileri: Öğretmenler sınıfta nasıl davranır? Ankara: Pegem Akademi.

Kızıltepe, Z. (2015). İçerik analizi. Nitel araştırma: Yöntem, teknik, analiz ve yaklaşımları. (Ed. Fatma Nevra Seggie \& Yasemin Bayyurt), (253-266), Ankara: Anı Yayıncılık.

Kitchenham, A. D. (2009). School cultures, teachers, and technology transformation. Canadian Journal of Learning and Technology, 35(29).

Masuda, Y. (1990). Managing in the information society. Cambridge: Basil Blackwell.

McMillan, J. H. \& Schumacher, S. (1989). Research in education: A conceptual introduction. (2nd ed). Glenview, IL: Scott, Foresman and Company.

Merriam, S. B. (2009). Qualitative research: A guide to design and implementation. San Francisco: Jossey-Bass.

Merton, R. K. (1968). Social theory and social structure. New York \& London: The Free Press.

Morgenroth, T., Ryan, M. K., and Peters, K. (2015). The Motivational theory of role modeling: How role models influence role aspirants' goals. Review of General Psychology, 19(4), 465-483.

Niess, M. L. (2012). Teacher knowledge for teaching with technology: a TPACK Lens. Educational technology, teacher knowledge, ans classroom impact: a research handbook on frameworks ans approaches içinde, (1-16), Hershey: IGI Global.

Ong, W. J. (2003). Sözlü ve yazılı kültür: Sözün teknolojikleşmesi. İstanbul: Metis Yayınları.

Papert, S. (1981). Mindstorm: children, computers, and powerful ideas. New York: Basic Books.

Papert, S. (1996). The connected family: bridging the digital generation gap. New York: Taylor Trade Publishing.

Postman, N. (1979). Teaching as a conserving activity. New York: Delacorte Press.

Seggie, F. N. \& Akbulut Yıldırmış, M. (2015). Nitel araştırmaların desenlenmesi. Nitel araştırma: Yöntem, teknik, analiz ve yaklaşımları. (Ed. Fatma Nevra Seggie \& Yasemin Bayyurt), (23-35), Ankara: Anı Yayıncılık.

Selwyn, N. (2011). Education and technology: Key issues and debates. New York: Continuum International Publishing Group.

Skinner, B. F. (1958). Teaching machines. Science, 128(3330), 969-977.

Stager, G. S. (15 Sept 2016). Seymour Papert (1928-2016): Father of educational computing. Nature, 537(7620), 308.

Stolp, S. \& Smith, S. C. (1995). Transforming school culture: Stories, symbols, values \& the leader's role. Oregon: ERIC Clearinghouse on Educational Management.

T.C Milli Eğitim Bakanlığı (2018). 2023 eğitim vizyonu. http://2023vizyonu.meb.gov.tr/doc/2023_EGITIM_VIZYONU.pdf

Turkle, S. (2015). Reclaiming conversation: The power of talk in a digital age. New York: Penguin Press.

Vygotsky, L. (1986). Thought and language. Cambridge, MA: MIT Press.

Wang, Y. (2001). Student teachers's perception and practice of the teacher's role when teaching with computers. The Journal of Educational Computing Research, Vol. 24(4), 419-434. 
